\title{
A CONCEPTUAL APPROACH TO FORMING A TRANSPORT AND LOGISTICS CLUSTER AS A COMPONENT OF THE REGION'S INNOVATIVE INFRASTRUCTURE (ON THE EXAMPLE OF PRYDNIPROVSKY ECONOMIC REGION OF UKRAINE)
}

\author{
Viacheslav Liashenko, Sergey Ivanov, and Nataliia Trushkina
}

\begin{abstract}
The analysis of the dynamics of the regional transport and logistics system of the Prydniprovsky economic region revealed many barriers to its effective functioning, which were divided into 10 groups: political, institutional, innovative, investment and financial, information, environmental, tariff, infrastructure, customs, and logistics. The forecast estimation of the indicators characterizing the development of the regional transport and logistic system in the Prydniprovsky economic region by using economic and mathematical tools was carried out, and on this basis tendencies of its functioning were revealed. It should be noted that forecast estimates should be considered forecasts-warnings. That is, provided that the insignificant level of labor productivity is maintained, as well as its reduction, the low return on capital investments in the coming years can significantly reduce the volume of transport (rail and road) in the Prydniprovsky economic region. Based on the regional development strategies of Dnipropetrovsk, Zaporizhzhia and Kirovohrad regions generalized, their shortcomings in creating a transport and logistics cluster were identified. In order to transform the regional innovation ecosystem, a conceptual approach to forming the transport and logistics cluster as an element of innovation infrastructure based on reasonable specialization was substantiated. It was proved that this structure should take the form of a partnership of business structures, research institutions, higher education institutions, institutions of logistics and innovation infrastructure, and government agencies. The structural scheme of interaction between the transport and logistics cluster and the innovation ecosystem was proposed to achieve the strategic goal of "Innovative development of the region on the basis of smart specialization" while implementing the strategic documents for the period till 2027. It was established that the development and implementation of basic conceptual provisions for forming a transport and logistics cluster would create appropriate conditions for increasing the volume and quality of transport and logistics services, for intensifying innovative development and implementing a qualitatively new regional pattern of sustainable development of the Prydniprovsky economic region, which must meet modern requirements for managing economic systems.
\end{abstract}

Keywords: regional economy, transport and logistics system, innovation ecosystem, transport and logistics cluster, indicators, barriers, structure, elements of innovation infrastructure, forecasting methods, economic and mathematical tools, conceptual approach, digital technologies, synergetic effect

JEL Classification: L91, O18, R12, R41, R58 


\section{Authors:}

Viacheslav Liashenko

Institute of Industrial Economics of NAS of Ukraine, Marii Kapnist Str., 2, Kyiv, 03057, Ukraine E-mail: slaval.aenu@gmail.com

https://orcid.org/0000-0001-6302-0605

\section{Sergey Ivanov}

Dnipropetrovsk State University of Internal Affairs, Ave. Gagarina, 26, Dnipro, 49005, Ukraine E-mail: ivanovsv@optima.com.ua

https://orcid.org/0000-0002-1205-3797

\section{Nataliia Trushkina}

Institute of Industrial Economics of NAS of Ukraine, Marii Kapnist Str., 2, Kyiv, 03057, Ukraine E-mail: nata_tru@ukr.net

https://orcid.org/0000-0002-6741-7738

Citation: Liashenko, V., Ivanov, S., \& Trushkina, N. (2021). A Conceptual Approach to Forming a Transport and Logistics Cluster as a Component of the Region's Innovative Infrastructure (on the Example of Prydniprovsky Economic Region of Ukraine). Virtual Economics. 4(1), 19-53. https://doi.org/10.34021/ve.2021.04.01(2)

Received: October 6, 2020. Revised: December 12, 2020. Accepted: January 3, 2021.

(C) Author(s) 2021. Licensed under the Creative Commons License - Attribution 4.0 International (CC BY 4.0) 


\section{Introduction}

The world is now undergoing global transformational changes in various spheres of economic activity. This requires the search for qualitatively new forms of management that would meet modern economic conditions. Businesses, including those of transport and logistics, are trying to unite for further development and operation. Therefore, the formation of a regional cluster structure of logistics management can create preferences for successful product promotion.

According to the experience of the EU countries, clustering is one of the conditions for increasing the competitiveness of national and regional economies. That is, in most European countries, clusters are recognized as an effective institution of social and economic development at various levels.

If we consider Ukraine, it should be noted that one of the key priorities of the "National Security Strategy of Ukraine", introduced by the Decree of the President of Ukraine dated 14.09.2020 No 392/2020, is the modernization of transport infrastructure (roads, railways, pipelines, airports, sea and river ports, etc.). This is in line with the EU-Ukraine Association Agreement, which deals with developing a multimodal transport network linked to the TransEuropean Transport Network (TEN-T) and the improvement of infrastructure policy to better identify and evaluate infrastructure projects for different modes of transport.

Given this, the strategic direction of developing transport and logistics systems in the economic regions of Ukraine is to improve the quality and availability of transport and logistics services, taking into account internal and interregional ties. To do this, it is necessary to create a transport and logistics cluster (TLC) as an element of innovation infrastructure in the context of balanced regional sustainable development at the level of the Prydniprovsky economic region of Ukraine, which meets the requirements of the European classification NUTS 1.

The purpose of the article is to scientifically and methodologically substantiate the conceptual approach to forming the transport and logistics cluster as a component of the regional innovation infrastructure on the example of the Prydniprovsky economic region of Ukraine. To achieve this purpose, there were applied the methods of analysis and synthesis, systematic approach, economic and statistical analysis, forecasting, comparisons and observations, grouping, structural and logical generalization.

\section{Literature Review}

Scientists study the issues related to the development of scientific approaches (system, integrated, logistics, etc.) in the theory of supply chain management and organization of logistics processes. Among them are: Beresford et al. (2005); Gunasekaran (2005); Huemer (2006); Blaik (2010); Kotler \& Keller (2014); Murphy \& Wood (2017); Bowersox \& Closs (2017); Dźwigoł \& Dźwigoł-Barosz (2018); Dźwigoł (2019, 2020a, 2020b, 2020c); Kwilinski (2018a, 2018b). 
The aspects of cluster development are actively researched by scientists and economists. Porter (1998) paid considerable attention to studying clusters and theoretically substantiated the cluster development of the economy.

According to the theory by Porter (1998), a cluster is a geographical concentration of interconnected companies that compete and cooperate with each other, as well as specialized suppliers, firms in relevant industries and related institutions in certain areas (for example, universities, standardization agencies, trade associations, etc.).

It is a group of geographically close interconnected companies and related institutions in a particular field on the basis of cooperation and complementarity. Thus, it is a group of geographically neighboring interconnected companies (suppliers, manufacturers) and related organizations (educational institutions, government agencies, infrastructure companies) that operate in a particular area and complement each other.

According to the European Cluster Collaboration Platform (2016), clusters are considered as regional ecosystems of related industries and competencies that have a wide range of intersectoral interdependencies. They are defined as groups of firms associated with economic entities and institutions that are located next to each other and have reached a sufficient scale for the development of specialized knowledge, services and skills.

A cluster is a sectoral, territorial and voluntary association of organizations that work closely with each other and with other actors in the value chain to increase the competitiveness of their products, their exports and promote economic development in the region (European Cluster Collaboration Platform, 2016).

Ukrainian researchers also did not overlook the issue of clustering. Thus, a significant contribution to the development of the clustering system was made by Voinarenko (2011), who considers the cluster approach from the standpoint of institutionalism. Sokolenko (2004) investigated in his works the influence of the cluster mechanism on innovative development.

Theoretical and methodological provisions and practical recommendations for forming transport and logistics clusters are reflected in the works by such scientists as: Zrobek (2011); Szuster (2012); Kruczek \& Zebrucki (2014); Frankowska (2015); Dmukhovski (2019); Hrytsenko (2019).

Ukrainian and foreign researchers (Hryhorak, 2017; Ivanov \& Kharazishvili, 2017; Nykyforuk, 2014, 2017; Ilchenko \& Karpenko, 2017; Nykyforuk et al., 2019; Dzwigol et al., 2019a, 2019b; Kwilinski, 2019; Dzwigol \& Dzwigol-Barosz, 2020; Dzwigol et al., 2020; Kharazishvili et al., 2020) pay much attention to developing theoretical, methodological and applied principles of forming a management system for the balanced development of the market of logistics services as a component of the national logistics system; to identifying areas for improving the efficiency of transport and logistics activities and key tasks and priorities for the development of the transport sector in Ukraine; to evaluating indicators of innovative development of the 
Ukrainian transport system to substantiate strategic guidelines; to identifying the global trends in digitalization, which include the use of big data and cloud technologies, the spread of the Internet of Things, the development of robotics, the spread of 3D printing, blockchain technology and crowdsourcing; to developing a functional scheme of digital transformation of the transport sector in Ukraine; to substantiating conceptual provisions of the strategy to develop the transport system of Ukraine and measures of the state policy of its realization.

In addition, it is necessary to note the research related to sustainable economic development and digital economy (Abazov 2021; Arefieva et al. 2021; Boiko et al. 2021; Bogachov et al. 2020; Borychowski et al. 2020; Burlaka et al. 2019; Chygryn et al. 2020; Czyżewski et al. 2019; 2020; Dalevska 2013; Dalevska et al. 2019; Dementyev 2013; 2015; 2019; Dementyev \& Scherbakov 2017; Dementyev \& Kwilinski 2020; Drozdz et al. 2019; 2020; Dzwigol 2019a; 2020c; 2021; Dzwigol \& Dzwigol-Barosz 2020b; Dzwigoł et al. 2019c; 2020a; 2020b; Gorynia 2019; Gorynia et al. 2019; Kaźmierczyk \& Chinalska 2018; Kharazishvili et al. 2021; Koibichuk et al. 2021; Kondratenko et al. 2020; Kuzior et al. 2019; Kvilinskyi 2012; Kvilinskyi \& Kravchenko 2016; Kwilinski et al. 2019a; 2019b; 2019c; 2019d; 2019e; 2019f; 2020a; 2020b; 2020c; 2020d; 2021; Kwilinski \& Kuzior 2020; Kyrylov et al. 2020; Lakhno et al. 2018; Lyulyov \& Pimonenko 2017; Lyulyov \& Shvindina 2017; Lyulyov et al. 2018; 2020a; 2020b; 2021a; 2021b; Melnychenko 2019; 2020; 2021; Mlaabdal et al. 2020; Miskiewicz 2017a; 2017b; 2018; 2019; 2020a; 2020b; 2021; Miśkiewicz \& Wolniak 2020; Pająk et al. 2016; 2017; Pimonenko \& Lyulyov 2019; Prokopenko \& Miskiewicz 2020; Saługa et al. 2020; Savchenko et al. 2019; Tkachenko et al. 2019a; 2019b; 2019c; 2019d; 2019e; Wyrwa \& Kaźmierczyk 2020).

\section{Methods}

The Prydniprovsky economic region (Dnipropetrovsk, Zaporizhzhia, Kirovohrad regions) has a significant logistical and transit potential for developing the regional transport and logistics system. This area has a favorable economic and geographical position, extensive interregional transport infrastructure and transport communications, which include the Prydniprovsky Railway, Berdiansk Sea Port, river ports, international airports, strategic highways in various directions and more.

However, the statistical analysis shows that in the economic region there is a tendency of insufficiently efficient development of the transport and logistics system. Thus, according to the State Statistics Service of Ukraine, the total volume of transit freight flows in Ukraine decreased in $2010-2014$ by $33.1 \%$ due to a reduction of rail transport by $34 \%$, water - by $78.2 \%$, aviation - by $25 \%$. Since 2015 , the value of this indicator has continued to decline. During 2010-2019, the total volume of transit freight reduced by $61.9 \%$ due to a decrease in the volume of rail transport by $54.3 \%$, water - by $90.8 \%$, air - by $68.8 \%$. Volumes of transit freight by road, on the contrary, increased by $95.7 \%$ in 2019 compared to 2010 (Table 1). 
Table 1. The Dynamics of Transit Cargo Flows in Ukraine, thousand tons

\begin{tabular}{cccccc}
\hline \multirow{2}{*}{ Years } & \multirow{2}{*}{ Total } & \multicolumn{3}{c}{ Including by mode of transport } \\
\cline { 3 - 6 } & & Automobile & Railway & Water & Aviation \\
\hline 2010 & 152353.8 & 4649.1 & 44511.8 & 3660.4 & 1.6 \\
\hline 2011 & 151243.0 & 5011.2 & 48669.5 & 3912.1 & 2.8 \\
\hline 2012 & 124893.9 & 4850.0 & 40940.1 & 1645.3 & 3.0 \\
\hline 2013 & 120126.6 & 5585.0 & 32983.0 & 1521.5 & 0.8 \\
\hline 2014 & 101993.4 & 5863.9 & 29398.3 & 797.3 & 1.2 \\
\hline 2015 & 91100.5 & 6402.2 & 27305.1 & 671.2 & 1.0 \\
\hline 2016 & 81371.0 & 6989.9 & 25361.0 & 564.9 & 0.9 \\
\hline 2017 & 72680.6 & 7631.6 & 23555.3 & 475.6 & 0.7 \\
\hline 2018 & 64918.3 & 8332.2 & 21878.2 & 400.4 & 0.6 \\
\hline 2019 & 57985.0 & 9097.1 & 20320.4 & 337.0 & 0.5 \\
\hline
\end{tabular}

Note: the data provided for 2015-2019 are a forecast; they are calculated using an autoregressive model. Source: State Statistics Service of Ukraine (2015b).

It should be noted that statistical data on transit cargo flows in the regions of Ukraine are not available. The analytical materials provide only the information on cargo processing in the sea and river ports in the regions. Thus, in 2010-2013 the volume of transit cargo in the river ports of Dnipropetrovsk region decreased by $41.7 \%$, or from 1.2 to 0.7 thousand tons. Since 2014, the processing of transit cargo in the river ports of the region has been completely stopped. The volumes of transit cargo in the seaports of Zaporizhzhia region decreased by $94.6 \%$, or from 115.6 to 6.2 thousand tons in 2010-2019 (State Statistics Service of Ukraine (2015a).

Table 2. The Dynamics of Cargo Volumes by Stevedoring Companies in the Berdiansk Seaport, thousand tons

\begin{tabular}{cccccc}
\hline \multirow{2}{*}{ Years } & \multirow{2}{*}{ Total volume } & \multicolumn{5}{c}{ Including by types of cargo } \\
\cline { 3 - 6 } & & export & import & domestic traffic & transit \\
\hline 2012 & 2538.2 & 2358.1 & 99.3 & 8.5 & 72.3 \\
\hline 2013 & 2163.5 & 1997.6 & 120.5 & 22.3 & 23.1 \\
\hline 2014 & 3197.1 & 2342.3 & 17.8 & 822.1 & 14.9 \\
\hline 2015 & 4450.8 & 2755.4 & 3.3 & 1692.1 & - \\
\hline 2016 & 3800.7 & 2806.6 & - & 994.1 & - \\
\hline 2017 & 2397.8 & 2164.2 & - & 233.6 & - \\
\hline 2018 & 1812.6 & 1782.9 & 17.3 & 12.4 & - \\
\hline 2019 & 2074.2 & 2035.1 & 38.6 & 0.5 & - \\
\hline
\end{tabular}

Source: The Ukrainian Sea Ports Authority (2020).

According to the Ukrainian Sea Ports Authority, the total volume of cargo processing by stevedoring companies in the Berdiansk seaport decreased by $18.3 \%$ in $2012-2019$. This is due to a reduction in the processing volume of export cargo - by $13.7 \%$, import - by $61.1 \%$,

Viacheslav Liashenko, Sergey Ivanov, and Nataliia Trushkina

Virtual Economics, Vol. 4, No. 1, 2021 
domestic traffic - by $94.1 \%$. During 2012-2014, the volume of transit cargo processing decreased by $79.4 \%$. And since 2015 , the processing of these goods has not been carried out due to military events. The share of cargo processing volumes in the Berdiansk seaport in 2019 was only $1.3 \%$ of the total Ukrainian volume (in $2012-1.7 \%$ ) (Table 2).

Exports of goods in the Prydniprovsky economic region increased by $1.1 \%$ in $2010-2019$ due to an increase in volumes from the Kirovohrad region by $109.9 \%$. Exports of goods from the Dnipropetrovsk region decreased by $1.4 \%$, from Zaporizhzhia region - by $4 \%$ (Table 3).

Table 3. The Dynamics of Goods Exported from the Prydniprovsky Economic Region, million dollars USA

\begin{tabular}{lcccc}
\hline \multirow{2}{*}{ Years } & $\begin{array}{c}\text { Prydniprovsky } \\
\text { economic region }\end{array}$ & Dnipropetrovsk & Zaporizhzhia & Kirovohrad \\
\cline { 3 - 5 } & 11568.7 & 8021.9 & 3210.0 & 336.8 \\
\hline 2010 & 14957.8 & 10363.2 & 4151.2 & 443.4 \\
\hline 2011 & 14765.1 & 10129.7 & 4004.8 & 630.6 \\
\hline 2013 & 14331.1 & 9795.3 & 3678.5 & 857.3 \\
\hline 2014 & 13314.8 & 8763.9 & 3730.2 & 820.7 \\
\hline 2015 & 9736.5 & 6398.9 & 2931.0 & 406.6 \\
\hline 2016 & 8585.3 & 5864.8 & 2292.8 & 427.7 \\
\hline 2017 & 10449.3 & 7052.8 & 2980.9 & 415.6 \\
\hline 2018 & 11621.6 & 7722.6 & 3377.2 & 521.8 \\
\hline 2019 & 11694.8 & 7907.2 & 3080.6 & 707.0 \\
\hline
\end{tabular}

Source: State Statistics Service of Ukraine (2020d).

During the period under research, the volume of goods imported to the Prydniprovsky economic region increased by $5.2 \%$ as a result of an increase in the Dnipropetrovsk region - by $2.5 \%$, Zaporizhzhia - by $12.2 \%$, Kirovohrad - by $33.4 \%$ (Table 4 ).

Table 4. The Dynamics of Goods' Imports into the Dnieper Economic Region, million dollars USA

\begin{tabular}{lcccc}
\hline \multirow{2}{*}{ Years } & $\begin{array}{c}\text { Prydniprovsky } \\
\text { economic region }\end{array}$ & Dnipropetrovsk & Zaporizhzhia & Kirovohrad \\
\cline { 3 - 5 } 2010 & 6938.2 & 5387.7 & 1363.0 & 187.5 \\
\hline 2011 & 9215.1 & 6717.2 & 2271.0 & 226.9 \\
\hline 2012 & 8836.6 & 6538.3 & 2013.4 & 284.9 \\
\hline 2013 & 7349.0 & 5346.5 & 1759.9 & 242.6 \\
\hline 2014 & 6418.3 & 4634.2 & 1582.4 & 201.7 \\
\hline
\end{tabular}




\begin{tabular}{lllcl}
\hline 2015 & 4416.2 & 3225.3 & 1085.5 & 105.4 \\
\hline 2016 & 4626.0 & 3443.6 & 998.4 & 184.0 \\
\hline 2017 & 6173.9 & 4609.6 & 1328.2 & 236.1 \\
\hline 2018 & 7290.8 & 5264.9 & 1762.8 & 263.1 \\
\hline 2019 & 7302.1 & 5522.2 & 1529.8 & 250.1 \\
\hline
\end{tabular}

Source: State Statistics Service of Ukraine (2020d).

At the same time, there is a positive balance of export-import operations: exports exceed imports of goods by 1.6 times. However, in 2010-2019, its value decreased by $5.1 \%$, or from 4630.5 to 4392.7 million US dollars.

According to the State Statistics Service of Ukraine, in 2000-2019, the volume of freight traffic by the Prydniprovsky Railway increased by $3.8 \%$, and its share in the all-Ukrainian volume increased by 5.5 percentage points, or from 31.6 to $37.1 \%$. Freight turnover of the Prydniprovsky Railway decreased by $21.6 \%$, and the share went down by 5.8 percentage points or from 23 to $17.2 \%$ of the national freight turnover of public railway transport (Table 5).

Table 5. Volumes of Freight Transportation and Freight Turnover of Public Railway Transport

\begin{tabular}{lcc}
\hline \multirow{2}{*}{ Years } & \multicolumn{3}{c}{ Prydniprovsky Railway } \\
\cline { 2 - 3 } & freight transportation, million tons & cargo turnover, billion tkm \\
\hline 2000 & 93.3 & 39.8 \\
\hline 2005 & 112.0 & 48.1 \\
\hline 2010 & 110.4 & 45.4 \\
\hline 2012 & 115.5 & 46.9 \\
\hline 2013 & 118.3 & 44.6 \\
\hline 2014 & 107.9 & 36.7 \\
\hline 2015 & 104.9 & 30.2 \\
\hline 2016 & 99.4 & 31.2 \\
\hline 2017 & 97.6 & 32.0 \\
\hline 2018 & 96.7 & 32.8 \\
\hline 2019 & 96.8 & 31.2 \\
\hline
\end{tabular}

Source: State Statistics Service of Ukraine (2019); State Statistics Service of Ukraine (2020c).

In 2010-2019, freight transportation volumes by rail in the Prydniprovsky economic region decreased by $7.8 \%$ as a result of a reduction in volumes in Dnipropetrovsk region by $8.7 \%$, Zaporizhzhia - by $4.6 \%$, Kirovohrad - by $2.1 \%$ (Table 6 ). 
Table 6. Volumes of Rail Freight Transportation in the Prydniprovsky Economic Region, thousand tons

\begin{tabular}{ccccc}
\hline \multirow{2}{*}{ Years } & $\begin{array}{c}\text { Prydniprovsky } \\
\text { economic region }\end{array}$ & Dnipropetrovsk & Zaporizhzhia & Kirovohrad \\
\cline { 3 - 5 } 2010 & $110,775.1$ & $90,836.0$ & $13,548.2$ & 6390.9 \\
\hline 2011 & $117,462.8$ & $94,215.0$ & $15,375.4$ & 7872.4 \\
\hline 2012 & $116,734.0$ & $93,723.0$ & $15,190.1$ & 7820.9 \\
\hline 2013 & $119,209.3$ & $96,774.0$ & $14,729.3$ & 7706.0 \\
\hline 2014 & $114,234.9$ & $93,261.0$ & $14,605.1$ & 6368.8 \\
\hline 2015 & $111,419.6$ & $90,533.0$ & $14,340.4$ & 6546.2 \\
\hline 2016 & $107,540.4$ & $85,848.0$ & $13,995.4$ & 7697.0 \\
\hline 2017 & $105,424.1$ & $83,951.0$ & $13,650.4$ & 7822.7 \\
\hline 2018 & $103,876.2$ & $83,481.0$ & $13,258.3$ & 7136.9 \\
\hline 2019 & $102,124.9$ & $82,941.0$ & $12,930.3$ & 6253.6 \\
\hline Source: developed by the authors. & & &
\end{tabular}

During the period analyzed, the volumes of freight transportation by road in the Prydniprovsky economic region decreased by $10.3 \%$ due to a reduction in volumes in the Dnipropetrovsk region by $6.3 \%$ and Zaporizhzhia - by $52.6 \%$. In the Kirovohrad region, on the contrary, there was a tendency to increase the volume of road freight by $37 \%$ (Table 7).

Table 7. Volumes of Road Freight Transportation by in the Prydniprovsky Economic Region, thousand tons

\begin{tabular}{lcccc}
\hline \multirow{2}{*}{ Years } & Prydniprovsky & \multicolumn{3}{c}{ Including regions } \\
\cline { 3 - 5 } & economic region & Dnipropetrovsk & Zaporizhzhia & Kirovohrad \\
\hline 2010 & 452196.2 & 359200.7 & 64914.5 & 28081.0 \\
\hline 2011 & 451087.1 & 355940.2 & 61838.2 & 33308.7 \\
\hline 2012 & 427221.4 & 345104.2 & 51403.4 & 30713.8 \\
\hline 2013 & 445391.9 & 376121.6 & 35073.5 & 34196.8 \\
\hline 2014 & 438834.3 & 361676.5 & 31427.4 & 45730.4 \\
\hline 2015 & 372689.6 & 300356.8 & 28497.8 & 43835.0 \\
\hline 2016 & 352062.8 & 284162.5 & 29050.4 & 38849.9 \\
\hline 2017 & 404312.4 & 328113.2 & 30396.5 & 45802.7 \\
\hline 2018 & 404321.0 & 324364.0 & 30715.2 & 49241.8 \\
\hline 2019 & 405815.6 & 336593.8 & 30742.5 & 38479.3 \\
\hline
\end{tabular}

Source: developed by the authors. 
Volumes of cargo transportation by the water transport (usually river) in the region surveyed decreased by $45.8 \%$ in 2019 compared to 2010 . This is due to a reduction in freight traffic in the Dnipropetrovsk region by $45.1 \%$ and Zaporizhzhia - by $47 \%$ (Table 8 ).

Table 8. Volumes of Water Freight Transportation in the Region, thousand tons

\begin{tabular}{lccc}
\hline \multirow{2}{*}{ Years } & \multirow{2}{*}{ Total volume of freight } & \multicolumn{2}{c}{ Including regions } \\
\cline { 3 - 4 } & & Dnipropetrovsk & Zaporizhzhia \\
\hline 2010 & 1065.7 & 650.3 & 415.4 \\
\hline 2011 & 1242.4 & 617.6 & 624.8 \\
\hline 2013 & 1097.5 & 597.9 & 499.6 \\
\hline 2014 & 936.5 & 517.2 & 419.3 \\
\hline 2015 & 836.6 & 256.3 & 580.3 \\
\hline 2016 & 819.6 & 419.7 & 399.9 \\
\hline 2017 & 877.3 & 532.8 & 344.5 \\
\hline 2018 & 763.1 & 466.4 & 296.7 \\
\hline 2019 & 663.8 & 408.2 & 255.6 \\
\hline
\end{tabular}

Source: developed by the authors.

During the study period, the volume of air freight transportation in the Prydniprovsky economic region decreased by $54.4 \%$. This occurred as a result of a significant reduction in volumes in Kirovohrad region by $75 \%$ and Dnipropetrovsk - by $30 \%$ (Table 9).

Table 9. Volumes of Air Freight Transportation in the Economic Region, thousand tons

\begin{tabular}{lcccc}
\hline \multirow{2}{*}{ Years } & $\begin{array}{c}\text { Prydniprovsky } \\
\text { economic region }\end{array}$ & Dnipropetrovsk & Zaporizhzhia & Kirovohrad \\
\cline { 3 - 5 } 2010 & 10.3 & 3.0 & 0.5 & 6.8 \\
\hline 2011 & 7.0 & 2.0 & 0.5 & 4.5 \\
\hline 2012 & 4.4 & 0.8 & 0.6 & 3.0 \\
\hline 2013 & 5.8 & 2.0 & 0.5 & 3.3 \\
\hline 2014 & 5.1 & 0.4 & 0.4 & 4.3 \\
\hline 2015 & 6.0 & 1.2 & 0.5 & 4.3 \\
\hline 2016 & 7.8 & 2.7 & 0.6 & 4.5 \\
\hline 2017 & 5.5 & 2.5 & 0.8 & 2.2 \\
\hline 2018 & 5.2 & 2.3 & 0.8 & 2.1 \\
\hline 2019 & 4.7 & 2.1 & 0.9 & 1.7 \\
\hline
\end{tabular}

Source: developed by the authors.

According to the analysis, the total freight turnover in the Prydniprovsky economic region (except for the Kirovohrad region, as there are no data on freight turnover in the statistical 
bulletins) decreased by $23.5 \%$ due to a reduction in rail freight turnover by $27.6 \%$, water freight turnover - by $39.8 \%$, air freight turnover - by $73.1 \%$. Road freight transport turnover increased by $41 \%$ in 2019 compared to 2010 (Table 10).

Table 10. Freight turnover by the means of transport, million tkm

\begin{tabular}{cccccc}
\hline \multirow{2}{*}{ Years } & \multirow{2}{*}{ Total } & \multicolumn{4}{c}{ Including by the means of transport } \\
\cline { 3 - 6 } & & automobile & railway & water & aviation \\
\hline 2010 & $44,088.5$ & 2795.4 & $41,178.5$ & 90.5 & 17.5 \\
\hline 2011 & $48,708.9$ & 2715.4 & $45,899.2$ & 76.1 & 13.1 \\
\hline 2012 & $44,775.1$ & 2771.3 & $41,895.2$ & 103.5 & 5.1 \\
\hline 2013 & $42,871.6$ & 2792.6 & $39,975.3$ & 96.9 & 6.8 \\
\hline 2014 & $38,294.9$ & 2996.5 & $35,255.5$ & 40.8 & 2.1 \\
\hline 2015 & $33,405.8$ & 3000.6 & $30,344.4$ & 55.9 & 4.9 \\
\hline 2016 & $35,785.4$ & 3458.4 & $32,259.0$ & 62.7 & 8.2 \\
\hline 2017 & $35,915.4$ & 3958.1 & $31,878.5$ & 72.8 & 5.8 \\
\hline 2018 & $34,544.8$ & 3767.1 & $30,711.4$ & 60.1 & 6.0 \\
\hline 2019 & $33,716.9$ & 3942.5 & $29,815.1$ & 54.5 & 4.7 \\
\hline
\end{tabular}

Source: developed by the authors.

During 2010-2019, the volume of direct investments in the field of transport and warehousing of the Prydniprovsky economic region decreased by $32.9 \%$. This is due to the reduction of direct investment in this type of economic activity of Zaporizhzhia region by $88.7 \%$ and Dnipropetrovsk region - by $21.4 \%$ (Table 11 ).

Table 11. The Dynamics of Direct Investments in the Field of Transport and Warehousing of the Prydniprovsky Economic Region, thousand dollars USA

\begin{tabular}{lcccc}
\hline \multirow{2}{*}{ Years } & \multirow{2}{*}{ Total volume } & \multicolumn{3}{c}{ Including regions: } \\
\cline { 3 - 5 } & & Dnipropetrovsk & Zaporizhzhia & Kirovohrad \\
\hline 2010 & $91,216.1$ & $71,249.6$ & $16,171.2$ & 3795.3 \\
\hline 2011 & $115,402.9$ & $94,447.2$ & $17,199.6$ & 3756.1 \\
\hline 2012 & $97,211.3$ & $85,608.8$ & 3694.2 & 7908.3 \\
\hline 2013 & $115,237.7$ & $107,065.2$ & 3920.8 & 4251.7 \\
\hline 2014 & $90,566.3$ & $83,911.9$ & 2949.6 & 3704.8 \\
\hline 2015 & $71,296.9$ & $66,142.0$ & 1672.8 & 3482.1 \\
\hline 2016 & $69,917.5$ & $63,822.6$ & 2660.9 & 3434.0 \\
\hline 2017 & $57,890.6$ & $52,007.4$ & 2591.8 & 3291.4 \\
\hline 2018 & $61,441.5$ & $55,035.3$ & 1750.5 & 4655.7 \\
\hline 2019 & $61,223.0$ & $56,017.8$ & 1829.2 & 3376.0 \\
\hline
\end{tabular}

Source: State Statistics Service of Ukraine (2020b). 
The share of capital investments in the transport sector of the economic region increased by 3.5 percentage points in 2019 compared to 2010 , or from $0.7 \%$ to $4.2 \%$ of the total volume of capital investments in the transport sector and warehousing (Table 12).

Table 12. The Dynamics of Capital Investments in the Field of Transport of the Prydniprovsky Economic Region, thousand UAH

\begin{tabular}{ccccc}
\hline \multirow{2}{*}{ Years } & \multirow{2}{*}{ Total volume } & \multicolumn{3}{c}{ Including regions: } \\
\cline { 3 - 5 } & & Dnipropetrovsk & Zaporizhzhia & Kirovohrad \\
\hline 2010 & 161,689 & 95,278 & 25,553 & 40,858 \\
\hline 2011 & 240,907 & 150,017 & 20,317 & 70,573 \\
\hline 2012 & 183,268 & 136,052 & 15,703 & 31,513 \\
\hline 2013 & 285,241 & 212,587 & 22,817 & 49,837 \\
\hline 2014 & 182,323 & 122,202 & 13,998 & 46,123 \\
\hline 2015 & 332,975 & 198,984 & 53,984 & 80,007 \\
\hline 2016 & 589,165 & 372,273 & 61,477 & 155,415 \\
\hline 2017 & $1,289,391$ & 902,509 & 113,215 & 273,667 \\
\hline 2018 & $2,098,340$ & $1,524,231$ & 357,685 & 216,424 \\
\hline 2019 & $2,159,623$ & $1,527,762$ & 523,150 & 108,711 \\
\hline Source: State Statistics Service of Ukraine (2020a). & &
\end{tabular}

Source: State Statistics Service of Ukraine (2020a).

The study (Ivanov et al., 2019a, 2019b, 2019c; Kwilinski \& Trushkina, 2019; Trushkina, 2019a, 2019b; Ivanov et al., 2020; Liashenko et al., 2020) proved that effective development of the regional transport and logistics system is constrained by many barriers, which can be divided into 10 groups:

- political: an unstable political situation in the country;

- institutional: an imperfect legislative and regulatory framework; a lack of a regional program and strategy for developing the transport and logistics cluster;

- innovative: insufficiently effective implementation of innovative activities and application of innovative technologies in the transport sphere;

- investment and financial: insufficient funding for the transport sector; ineffective implementation of the public-private partnership mechanism; limited tools for private investment in logistics and innovation infrastructure;

- environmental: inefficient application of the "green" logistics concept in the transport sector;

- informational: insufficient use of information and communication technologies and digital logistics tools;

- tariff: high level of tariffs and costs for the organization of logistics activities;

- infrastructural: significant violations of existing logistics infrastructure facilities; limited infrastructure capacity;

- customs: significant time for document circulation and passing customs procedures; 
- logistics: inefficient organization of logistics activities; uncoordinated work of Ukrzaliznytsia and its regional branches; reducing the level of service and quality of transport and logistics services; reduction of freight traffic by different means of transport; complexity and unpredictability in tariffs and delivery times.

Thus, as can be seen from the analysis, in the Prydniprovsky economic region, first of all, the ground type of transport (rail and road) is developing. The situation in the air and water transport is deteriorating every year and requires considerable attention from regional and local authorities, transport and logistics companies, private investors for joint efforts on anticrisis management of the transport system.

Based on the fact that the indicators that characterize the development of the transport and logistics system in the Prydniprovsky economic region are represented by time series for 20102019 , the main forecasting models are based on trend and integrated autoregressive models that adequately reflect trends and patterns of change in time series.

The choice of the optimal approximation model is based on the essential characteristics of the calculation results and the optimal combination of formal approximation criteria, in particular, $\min \sum\left(y_{t}-\hat{y}_{t}\right)^{2}$, - the least squares method (LSM criterion), min $\varepsilon_{\text {rel. }}$ - the minimum value of the relative approximation error and $\max F$-criterion - the maximum value of the FisherSnedekor criterion. Algorithms for mathematical and statistical modeling are described in detail in the literature on mathematical statistics, econometrics, statistical modeling and forecasting (Box \& Jenkins, 1974; Shelobaev, 2000; Yerina, 2001; Shamileva, 2008). From all the calculated models for analysis and forecasting based on certain criteria, the optimal one is selected.

For example, the dynamics of freight forwarding by the Prydniprovsky Railway has an autocorrelation component, so the optimal model is an integrated autoregressive model, in particular the model of moving average and autoregression (ARMA) or a model implemented by the OLYMP algorithm. The value of the relative error of the approximation ( $\varepsilon_{\text {rel. }}=5.5 \%$ ) indicates the statistical accuracy of the model and provided that $F_{p}>F_{\alpha}\left(F_{p}=6.4 ; F_{\alpha}=3.26\right)$, the corresponding model adequately reflects the regularity of changes in the levels of time series and can be used for modeling and prognostication.

Thus, the trend of changes in freight traffic by the Prydniprovsky Railway corresponds to the ARMA-model, and forecast estimates based on it show that in the next three years (20212023) the volume of shipments may reach 106.9 million tons. Forecast estimates of cargo turnover were calculated similarly (Table 13). 
Table 13. Forecast Estimates of Freight Traffic by the Prydniprovsky Railway for 2021-2023

\begin{tabular}{|c|c|c|c|c|c|}
\hline \multirow[t]{2}{*}{ Indicators } & \multirow{2}{*}{$\begin{array}{l}\text { Optimal approximation } \\
\text { model, } \varepsilon_{\text {rel. }} \\
F \text {-criterion }\end{array}$} & \multirow{2}{*}{$\begin{array}{l}\text { Actual level } \\
2019\end{array}$} & \multicolumn{3}{|c|}{$\begin{array}{l}\text { Forecast estimates for the period } \\
\text { of bias }\end{array}$} \\
\hline & & & 2021 & 2022 & 2023 \\
\hline $\begin{array}{c}\text { Cargo } \\
\text { transportation } \\
\left(y_{1}\right) \\
\text { million tons }\end{array}$ & $\begin{array}{c}\text { Integrated } \\
\text { autoregressive model } \\
\text { OLYMP; } \\
\varepsilon_{\text {rel. }}=5.5 \% ; \\
F_{p}=6.4 \\
F_{\alpha}\left\{\begin{array}{l}\alpha=0,1 \\
V_{1}=1 \\
V_{2}=10\end{array}\right\}=3.26 ; \\
F_{p}>F_{\alpha}\end{array}$ & 96.8 & 106.3 & 106.8 & 106.9 \\
\hline $\begin{array}{l}\text { Freight turnover } \\
\qquad\left(y_{2}\right), \\
\text { billion tkm }\end{array}$ & $\begin{array}{c}\text { Model OLYMP; } \\
\begin{array}{c}\varepsilon_{\text {rel. }}=9.8 \% \\
F_{p}=16.0\end{array}\end{array}$ & 31.2 & 35.3 & 35.8 & 36.2 \\
\hline
\end{tabular}

Source: calculated by the authors.

These calculations show that in 2000-2018 there were conditions that provide a slight increase in freight traffic by the Prydniprovsky Railway. Over the past five years, freight traffic has fallen by $7.7 \%$. But according to forecasts, they may increase as of 2021 to 106.3 million tons, or $9.8 \%$ compared to 2019 , and in five years (until 2023) this increase may be $10.4 \%$. Approximately the same picture has developed for freight turnover: they may increase to 36.2 billion tkm in 2023 , which is $16 \%$ by 2019 . Forecast estimates of road freight traffic in the Prydniprovsky economic region are based on these models (Table 14).

Table 14. Forecast Estimates of the Road Freight Transportation Volume in the Prydniprovsky Economic Region

\begin{tabular}{cccccc}
\hline & $\begin{array}{c}\text { Optimal approximation model, } \\
\text { Indicators }\end{array}$ & $\begin{array}{c}\varepsilon_{\text {rel. }} \\
F-\text { criterion }\end{array}$ & Actual level & \multicolumn{3}{c}{$\begin{array}{c}\text { Forecast estimates for the } \\
\text { period of bias }\end{array}$} \\
\cline { 4 - 6 } & Prydniprovsky economic region & & & \\
\hline $\begin{array}{c}\text { Freight } \\
\text { transportation } \\
\left(y_{4}\right), \\
\text { million tons }\end{array}$ & $\begin{array}{c}\text { Additive model: } \\
y_{4}=y_{5}+y_{6}+y_{7}\end{array}$ & 405.8 & 458.6 & 462.1 & 467.8 \\
\hline $\begin{array}{c}\text { Cargo turnover } \\
\left(y_{8}\right), \\
\text { million tkm }\end{array}$ & $\begin{array}{c}\text { Additive model: } \\
y_{8}=y_{9}+y_{10}+y_{11}\end{array}$ & 7562.5 & 9337.8 & 9766.0 & 10219.8 \\
\hline
\end{tabular}




\begin{tabular}{|c|c|c|c|c|c|}
\hline \multicolumn{6}{|c|}{ including: Dnipropetrovsk region } \\
\hline $\begin{array}{c}\text { Freight } \\
\text { transportation } \\
\left(y_{5}\right) \\
\text { million tons }\end{array}$ & $\begin{array}{c}\text { Integrated autoregressive } \\
\text { model OLYMP; } \\
\varepsilon_{\text {rel. }}=11.7 \%\end{array}$ & 336.6 & 363.7 & 362.7 & 363.7 \\
\hline $\begin{array}{l}\text { Cargo turnover } \\
\left(y_{9}\right) \\
\text { million tkm }\end{array}$ & $\begin{array}{c}\text { Integrated autoregressive } \\
\text { model of Box-Jenkins (ARMA); } \\
\varepsilon_{\text {rel. }}=6.5 \% ; F_{p}=27.7\end{array}$ & 4888.4 & 5754.9 & 5960.6 & 6166.3 \\
\hline \multicolumn{6}{|c|}{ Zaporizhzhia region } \\
\hline $\begin{array}{c}\text { Freight } \\
\text { transportation } \\
\left(y_{6}\right) \\
\text { million tons }\end{array}$ & $\begin{array}{l}\text { Integrated autoregressive } \\
\text { model OLYMP; } \\
\varepsilon_{\text {rel. }}=5.1 \% ; F_{p}=20.7\end{array}$ & 30.7 & 35.6 & 36.3 & 37.0 \\
\hline $\begin{array}{l}\text { Cargo turnover } \\
\qquad\left(y_{10}\right) \\
\text { million tkm }\end{array}$ & $\begin{array}{c}\text { Parabolic trend; } \\
\varepsilon_{\text {rel. }}=7.0 \% ; \quad F_{p}=39.7\end{array}$ & 1532.0 & 1787.5 & 1936.3 & 2110.8 \\
\hline \multicolumn{6}{|c|}{ Kirovohrad region } \\
\hline $\begin{array}{c}\text { Freight } \\
\text { transportation } \\
\left(y_{7}\right) \\
\text { million tons }\end{array}$ & $\begin{array}{c}\text { Parabolic trend; } \\
\varepsilon_{\text {rel. }}=6.7 \% ; \quad F_{p}=32.0\end{array}$ & 38.5 & 59.3 & 63.1 & 67.1 \\
\hline $\begin{array}{l}\text { Cargo turnover } \\
\qquad\left(y_{11}\right) \\
\text { million tkm }\end{array}$ & $\begin{array}{c}\text { Integrated autoregressive } \\
\text { model of Box-Jenkins (ARMA); } \\
\varepsilon_{\text {rel. }}=14.0 \% ; \\
F_{p}=13.2\end{array}$ & 1142.1 & 1795.4 & 1869.1 & 1942.7 \\
\hline
\end{tabular}

Source: calculated by the authors.

Calculations show that in the district as a whole in the next five years the volume of traffic may increase by $15.3 \%$ and reach 467.8 million tons. It should be noted that according to forecast estimates, the largest growth rates of freight transportation are in the Kirovohrad region - as of 2023 , their growth may reach $74.3 \%$, and freight turnover $-70.1 \%$. This ratio indicates that a slight reduction in the distance of cargo transportation in the region is possible.

The lowest growth rates of cargo volumes are in the Dnipropetrovsk region; in five years they can grow by $8.1 \%$ with an increase in cargo turnover by $26.1 \%$. In Zaporizhzhia region, according to forecast estimates, it is possible to increase freight turnover by $37.8 \%$ by 2023 , both due to direct volumes of transportation by $20.5 \%$ and to a significant increase in the distance of transportation by $16.8 \%$.

Consider the factor model of changing the results of transport activities of the Prydnieprovsky economic region. The results of transport, which are represented by the total volume of rail and road freight, depend on the number of employees and their productivity, as well as capital 
investment in transport and warehousing. To determine the influence of these factors, multifactor regression dependences of the following type are used.

- linear model:

$$
\begin{aligned}
& \hat{y}_{x i}=763.5-5.92 x_{1}+0.012 x_{2}-6.117 t ; \\
& D_{\hat{y}_{x i}}=0.825 ; \varepsilon_{\text {rel. }}=2.2 \% ; F_{p}=7.84 ; \\
& F_{\alpha}=\left\{\begin{array}{l}
\alpha=0.05 \\
V_{1}=3 \\
V_{2}=5
\end{array}\right\}=5.41 ; F_{p} \geq F_{\alpha}
\end{aligned}
$$

- power model:

$$
\begin{aligned}
& \hat{y}_{x i}=1749.4 x_{1}^{-0.423} \cdot x_{2}^{0.053} e^{-0.012 t} ; \\
& D_{\hat{y}_{x i}}=0.821 ; \varepsilon_{\text {rel. }}=0.3 \% ; F_{p}=7.67
\end{aligned}
$$

where $y_{t}$ means volumes of cargo transportation by transport of the Prydnieprovsky economic region for 2010-2018, million tons;

$x_{1}$ is an average number of full-time employees in the field of transport, thousand people; $x_{2}$ is capital investments in the field of transport and warehousing (in actual prices), UAH million;

$t=\{1,2,3,4,5,6,7,8,9\}$ is a time factor or serial number of the year.

The inclusion of the time factor $(t)$ in the regression equation as an additional independent variable is due to the fact that the objects of observation are taken as time series - to ensure the independence of the time series levels for the objects of observation.

The statistical reliability and accuracy of the models $\left(\varepsilon_{r e l .} \leq 15.0 \% ; F_{p}>F_{\alpha}\right)$ indicates that certain measures of correlation are objective and can be extended beyond the observation period.

In 2010-2018, the impact of living labor costs, i.e., the number of full-time employees is reversed, the growth of the employees' contingent is accompanied by a decrease in shipments. For example, according to equation (2), each percentage increase in the number of full-time employees is accompanied by a decrease in rail and road shipments of goods by $0.423 \%$, provided that at the same time there are changes in capital investment. The defined measure of communication shows that the use of living labor costs in the transport of the Prydnieprovsky economic region is not even extensive, but de-intensive, and is accompanied by a decrease in labor productivity. The impact of capital investment is direct, but the degree of communication is negligible. In particular, each percent of their growth is accompanied by an increase in shipments by $0.053 \%$, provided that both affect the volume and cost of living labor. The time factor shows that over the past nine years there has been a negative trend, 
especially until 2016. Despite the slight increase in traffic in 2017-2018, there is a downward trend. In general, all factors determine changes by $82.1 \%$ in total freight traffic.

Based on the above regression models, it is possible to determine the forecast values of cargo shipments, taking into account both trends in factors and the extent of their impact on cargo volumes. At the first stage, their forecast estimates are calculated by the method of extrapolation according to the optimal model of the corresponding series $\left(x_{1}, x_{2}\right)$. The second stage includes calculations of the already directly effective feature $\left(y_{t}\right)$ by a specific regression equation (Table 15).

Table 15. Forecast Estimates of Rail and Road Freight Transportation by in the Prydniprovsky Economic Region

\begin{tabular}{|c|c|c|c|c|c|c|c|}
\hline \multirow[b]{2}{*}{ Indicators } & \multirow{2}{*}{$\begin{array}{c}\text { Optimal } \\
\text { approximation } \\
\text { model, } \varepsilon_{\text {rel. }} \\
F-\text { criterion }\end{array}$} & \multirow{2}{*}{$\begin{array}{l}\text { Actual } \\
\text { level } \\
2018\end{array}$} & \multicolumn{5}{|c|}{ Forecast estimates for the period of bias } \\
\hline & & & 2019 & 2020 & 2021 & 2022 & 2023 \\
\hline $\begin{array}{c}\text { The average } \\
\text { number of full- } \\
\text { time employees } \\
\left(x_{1}\right) \text {, thousand } \\
\text { people }\end{array}$ & $\begin{array}{c}\text { Parabolic trend; } \\
\varepsilon_{\text {rel. }}=4.1 \% \\
F_{p}=3.1\end{array}$ & 41.7 & 44.5 & 45.7 & 46.9 & 48.2 & 49.5 \\
\hline $\begin{array}{l}\text { Capital } \\
\text { investments } \\
\qquad\left(x_{2}\right) \\
\text { million UAH }\end{array}$ & $\begin{array}{c}\text { Integrated } \\
\text { autoregressive } \\
\text { model OLYMP; } \\
\qquad \varepsilon_{r e l .}=20.0 \% ; \\
\qquad F_{p}=2.6\end{array}$ & 3325.7 & 3644.1 & 3966.0 & 4250.3 & 4497.0 & 4705.9 \\
\hline $\begin{array}{l}\text { Volumes } \\
\text { of rail and road } \\
\text { freight }\end{array}$ & $\begin{array}{c}\text { Linear regressive } \\
\text { model (1); } \\
\varepsilon_{r e l .}=2.2 \% ; \\
F_{p}=7.84\end{array}$ & 501.0 & 482.6 & 473.3 & 464.0 & 452.7 & 441.4 \\
\hline $\begin{array}{c}\left(y_{t}\right) \\
\text { million tons }\end{array}$ & $\begin{array}{c}\text { Power regressive } \\
\text { model (2); } \\
\varepsilon_{\text {rel. }}=0.3 \% ; \\
F_{p}=7.67\end{array}$ & 501.0 & 481.4 & 472.2 & 463.2 & 453.8 & 444.6 \\
\hline
\end{tabular}

Source: calculated by the authors.

It should be noted that changes in the volume of capital investment have a fairly high level of variation throughout the period, for example, in 2014-2016, their volumes were almost 3-3.5 times less than in 2011 or in 2018. Such regularity has determined a rather low level of adequacy and statistical accuracy of this series, $\varepsilon_{\text {rel. }}=20 \%$, so the forecast estimates of capital investment by the model have a probability of their implementation by $80 \%$. 
Provided that the trends of factors and strength change and the direction of their impact on the total volume of cargo transportation in the Prydnieprovsky economic region, according to forecast estimates, will be reduced. Thus, as of 2020, the volume of cargo transportation may be at the level of 482.6 million tons, which is $3.7 \%$ less than in 2018, and by 2023 this decrease may reach $12 \%$. Almost the same values of forecast estimates were obtained for both equation (1) and equation (2), which confirms the accuracy of the calculations.

Thus, these estimates can be considered forecasts - a warning. That is, provided that the insignificant level of labor productivity is maintained and it is reduced, the low return on capital investment in the coming years may significantly reduce the volume of transport (railway and road) of the economic region.

\section{Results}

To date, the Regional Development Strategies for 2021-2027 have been developed and approved in Dnipropetrovsk, Zaporizhzhia and Kirovohrad regions (Table 16). These strategic documents meet the Goals of sustainable development until 2030 and the main provisions of the State Strategy for Regional Development until 2027 "Development and Unity Oriented to People", which includes the formation of a cohesive country in social, economic, environmental and spatial dimensions. This goal should be achieved through the development of infrastructure (including transport) to support the provision of public services and increase the investment attractiveness of the territories.

Table 16. Analysis of Regional Development Strategies for the Period up to 2027 in Terms of Forming Transport and Logistics Clusters

\begin{tabular}{cccc}
\hline Component & Dnipropetrovsk region & Zaporizhzhia region & Kirovohrad region \\
\hline $\begin{array}{c}\text { Strategic } \\
\text { goal }\end{array}$ & $\begin{array}{c}\text { Ensuring quality living } \\
\text { conditions. Innovative } \\
\text { development of the region } \\
\text { based on smart- } \\
\text { specialization }\end{array}$ & $\begin{array}{c}\text { Competitive economy of the } \\
\text { region (which develops on } \\
\text { the basis of smart } \\
\text { specialization) in the } \\
\text { national and global space }\end{array}$ & $\begin{array}{c}\text { Competitive } \\
\text { innovation-oriented } \\
\text { economy, which } \\
\text { develops on the basis } \\
\text { of smart specialization }\end{array}$ \\
\hline $\begin{array}{c}\text { Operational } \\
\text { goal }\end{array}$ & $\begin{array}{c}\text { Development of the } \\
\text { region's infrastructure, } \\
\text { landscaping. Creating a } \\
\text { transport cluster }\end{array}$ & $\begin{array}{c}\text { Modernization of transport } \\
\text { and logistics infrastructure } \\
\text { in the conditions of external } \\
\text { challenges }\end{array}$ & $\begin{array}{c}\text { Creating a favorable } \\
\text { climate for } \\
\text { investment }\end{array}$ \\
\hline
\end{tabular}

Source: compiled by the authors.

The Strategy of Regional Development of Zaporizhzhia region for the period till 2027 deals with forming cluster initiatives in various spheres of economic activity, the creation of a large multimodal logistics center for transportation and storage of goods with the construction of a cargo terminal. Modernization of transport and logistics infrastructure should be carried out by supporting the development of infrastructure of river and sea ports; reconstruction of 
airports; integration of the transport network and infrastructure into the Trans-European Transport Network (TEN-T).

The Development Strategy of Dnipropetrovsk region for the period till 2027 provides for the creation of a transport cluster that will facilitate the organization of a transport hub with the development of infrastructure for all means of transport - road, rail, water, aviation.

As stated in the Development Strategy of Kirovohrad region for 2021-2027, it is possible to create a favorable climate for attracting investment as a result of modernization and further development of road transport infrastructure and logistics potential.

Summarizing the above strategic programs, it was found that only in Dnipropetrovsk region (with the involvement of specialists from the Institute of Industrial Economics of the NAS of Ukraine and the Academy of Economic Sciences of Ukraine) there was indicated the creation of a transport cluster as a promising area of smart specialization in the region.

The strategic documents of Zaporizhzhia and Kirovohrad regions do not currently indicate the need in forming transport and logistics clusters as a key component of regional innovation ecosystems, and do not prescribe the financial mechanism for their operation with nontraditional sources of investment and financial instruments, including international -privatepublic partnership. There are no measures in the Implementation Plans of the Development Strategies of Zaporizhzhia and Kirovohrad oblasts to promote the creation and intensive functioning of transport and logistics clusters.

In order to modernize the innovation infrastructure of the Prydniprovsky economic region, it is advisable to develop the Concept of creating a transport and logistics cluster, the essence and main elements of which are given below.

\section{Introduction}

Ensuring the sustainable development of the Prydniprovsky economic region in the context of intensifying the European integration processes requires the search for qualitatively new tools to increase their competitiveness and investment attractiveness, including a cluster pattern of logistics. At the same time, the main mechanisms for implementing the Regional Development Strategies for 2021-2027, which are based on the Laws of Ukraine "On Principles of State Regional Policy", "On Stimulating Regional Development" and the project "Support to Regional Development Policy in Ukraine", implemented within the EU, include a clustering mechanism, which involves the development of a concept for forming regional clusters and a system of measures for financial incentives for cluster initiatives.

This is in line with the EU Clustering Manifesto (Brussels, 2007) and the European Cluster Memorandum (Stockholm, 2008), which currently define the development strategy of the European and global community and are based on the principles of regional cluster policy through functioning of economic entities, relevant regions, including the transport and logistics sector that serves them. 


\section{The Problem Definition}

The main problems in the functioning of the transport and logistics system of the Prydniprovsky economic region include the following:

- an imperfect legislative and regulatory framework for regulating the transport system development; a lack of a regional program, concept and strategy for developing the transport and logistics cluster;

- insufficient funding of the transport sector due to inefficient implementation of the international-private-public partnership; limited tools for private investment in logistics infrastructure;

- a lack of "green" investment tools for transport and logistics infrastructure in the region;

- a limited use of the "green" logistics concept in the transport sector;

- an insufficient use of information and communication technologies and digital logistics tools;

- inefficient organization of logistics activities, reducing the level of service and quality of transport and logistics services.

\section{The Goal}

Development and implementation of basic conceptual provisions for forming a transport and logistics cluster will create appropriate conditions for the growth and quality of transport and logistics services, as well as will implement a qualitatively new regional model of sustainable development in the Prydniprovsky economic region, which will meet modern economic requirements.

\section{Ways to Solve the Problem}

To eliminate key barriers that hinder the effective functioning of the regional transport and logistics system, it is necessary to create a transport and logistics cluster as a form of partnership of business structures (transport and logistics companies, small businesses, consumers of transport and logistics services), institutions of higher education and science, logistics infrastructure institutions and authorities in order to transform the regional innovation ecosystem (Figure 1). The organizational and legal form of this structure can be an association or a public organization.

The key purpose of creating this institute of regional development is to:

- reduce logistics costs due to modernization of existing transport infrastructure;

- provide a comprehensive door-to-door service with all means of transport involved, with the construction of terminal complexes, regional logistics centers, creating a new type of structure (logistics operator) to service the transport and logistics system.

The main principles of forming a transport and logistics cluster include:

- creating a network of logistics centers, including transport terminals, distribution and trade complexes;

- developing and implementing a single information and management system to optimize, monitor and manage traffic flows in cyberspace; 
- delivering products "door to door", "in the right place and on time" based on the developing multimodal and combined transportation.

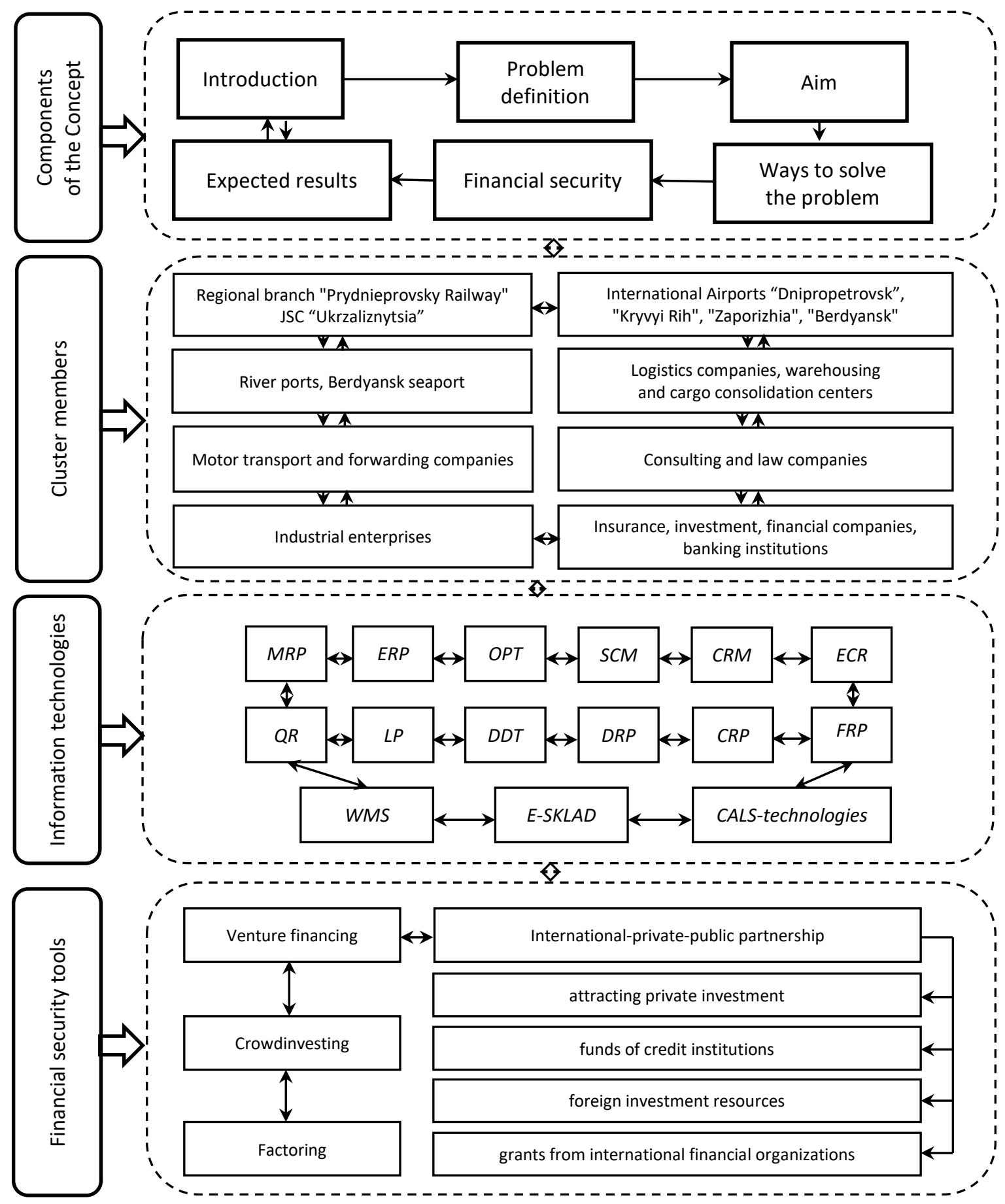

Figure 1. A Conceptual Approach to Forming a Transport and Logistics Cluster in the Prydniprovsky Economic Region.

Source: developed by the authors. 
The motivation of TLC participants is to increase the operation efficiency and the level of products and services competitiveness by maximizing profits and minimizing the cost of logistics activities as a result of optimizing traffic flows.

When organizing the processes of logistics, it is advisable to use a set of modern information technologies, which are conditionally systematized by the process approach:

- design - CAD (computer-aided product design);

- CAM (computer-aided manufacturing);

- scheduling - CAP (computer-aided planning);

- CAE (computer support of calculations and simulations);

- CRP (capacity planning);

- FRP (financial resource planning);

- logistics - MRP (material needs planning);

- MRPII (resource planning);

- ERP (integrated enterprise resource planning);

- production management - CIM (computer integrated manufacturing);

- OPT (optimization of production technology);

- PPC (production planning and management);

- PC (production control);

- LP ("savings production");

- warehouse management - WMS (warehouse management system);

- E-SKLAD (automated warehouse management system);

- customer service management - CRM (customer relationship management);

- ECR (system of effective consumer response);

- distribution management - DRP I (product distribution management and planning system);

- DRP II (resource planning in distribution);

- quality management - QA (quality analysis);

- CAQ (computer-aided quality control);

- SQC (statistical quality control);

- TQC (integrated quality control);

- TQM (integrated quality management);

- controlling - CONWIP (system of constant control in the course of work).

It should be noted that the cooperation of the transport and logistics cluster with elements of innovation infrastructure (Figure 2) should be to:

- participate in implementing Development Strategies of Dnipropetrovsk, Zaporizhzhia and Kirovohrad regions until 2027 in terms of the task to create a transport cluster; working group meetings;

- develop the Concept of creating a transport cluster and Regulations on a transport cluster;

- conduct joint research with the Prydniprovsky Research Center of the National Academy of Sciences of Ukraine and the Ministry of Education and Science of Ukraine on modernization of the innovation ecosystem based on forming a TLC; 
- organize scientific and methodological support of the Concept;

- hold round tables and conferences to discuss problems, etc.

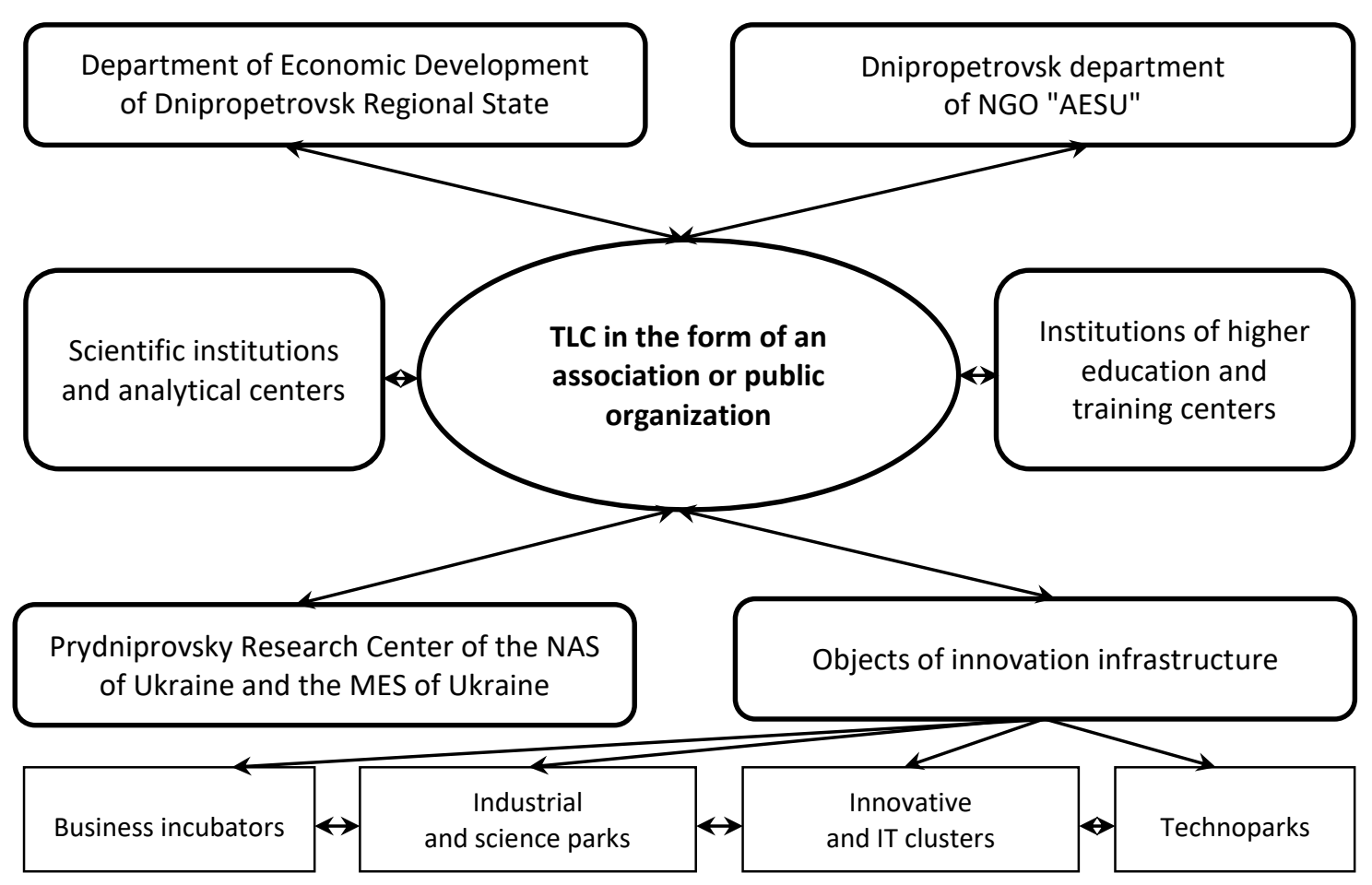

Figure 2. A Structural Scheme of the Interaction among the Elements of the Regional Innovation Ecosystem to Achieve the Strategic Goal "Innovative Development of the Region Based on Smart-Specialization"

Source: developed by the authors.

\section{Financial Security}

The Concept should be implemented using financial instruments such as venture capital, crowdfunding, factoring, international public-private partnership based on attracting private investment, credit institutions, foreign investment resources, grants from international financial organizations and more.

The Public-Private Partnership in Infrastructure survey conducted by the Center for Transport Strategies and Deloitte (2018) shows that $85 \%$ of respondents (experts from international financial institutions (IFIs), shippers, existing port and railway operators control more than $90 \%$ of freight traffic in Ukraine) consider attracting private capital as a key goal of publicprivate partnership (PPP) for developing large infrastructure projects. $77 \%$ of respondents consider PPP as an option when the state cannot implement the project on its own. Other project objectives include improving the quality of infrastructure (35\%); reducing corruption (35\%); improving the level and quality of infrastructure services (31\%); reducing project costs (19\%); decreasing the level of state risks and simplifying implementation (12\%). 
All participants in the transport services market recognize PPP as the best mechanism for financing projects. However, the respondents did not agree on the advantages of PPP compared to budget funding. Shippers, port operators and IFls name the most significant factor in reducing the risks of inefficient and excessive spending of budget funds $158 \%$ of experts); railway operators mention rapid implementation of the plans to modernize transport infrastructure (46\%). At the same time, $35 \%$ of respondents say that PPP will be an important factor in increasing the country's investment attractiveness. $46 \%$ of respondents consider the quality of the constructed objects and terms of realization to be unequivocal advantages. Also, business (50\% of respondents) prefers PPP as the most transparent investment mechanism compared to the budget, but IFls do not share this opinion.

It should be noted that $85 \%$ of respondents say that sea and river ports have the highest potential for PPP development in Ukraine. $65 \%$ of respondents see the development of PPP in the railway industry; $54 \%$ - in the field of road transport. And only $27 \%$ named airports and $8 \%$ - municipal transport.

The majority of respondents (92\%) call concession the main form of partnership between the state and business: port operators and IFIs (100\%), shippers (89\%), railway operators (83\%). Despite the fact that the concession is recognized as a priority tool, for each infrastructure project the choice of cooperation mechanism should be individual: $50 \%$ of respondents consider joint activities to be the optimal form of PPP; $44 \%$ - property lease; $35 \%$ privatization of state property. At the same time, $23 \%$ of respondents agree that the management of state property is not the best example of PPP.

According to the results of the study "Improving the management of the port industry of Ukraine", conducted by the World Bank (2020), for the management of the port industry in the regions it is advisable to implement the Port-Landlord pattern, which is used in some countries, such as the Netherlands (Antwerp, Rotterdam), Singapore. This management pattern provides for the existence of a port administration that controls port property, which allows it to develop the land use policy and consistent planning, transferring access to property to service providers and investors through contracts (concessions). The Port-Landlord pattern is based on the following principles: the port administration, which has the right of ownership or otherwise controls the use of port territories, is responsible for the planning and integrated development of ports; private operators carry out stevedoring activities under a concession or lease agreement for assets and land with the port administration.

Implementation of the mechanism of international-private-public partnership can lead to successful planning of transport infrastructure development and provision of integrated multimodal logistics services; effective provision of connections among different means of transport and their integration with cities and territorial communities; increasing the economic potential of transport and logistics infrastructure to attract private investment. 


\section{Expected Result}

The creation and development of a transport and logistics cluster in the Prydniprovsky economic region as an element of the regional innovation infrastructure will contribute to:

The annual growth of:

- volumes of rail freight transportation by $5 \%$ and freight turnover of the Prydniprovsky Railway by $2 \%$;

- volumes of road freight transportation by $6 \%$ and road freight turnover by $16 \%$;

- the density of public roads paved ( $\mathrm{km}$ per 1 thousand $\mathrm{km} 2$ of the region) by $2 \%$;

- the average daily productivity of the locomotive (thousand tkm gross) of the Prydniprovsky Railway by $2.4 \%$;

- average daily productivity of a freight truck (tkm net) by $17.5 \%$;

- the average precinct speed of the freight train ( $\mathrm{km}$ per hour) by $1 \%$;

- the level of logistics services for service consumers (\%) by $3 \%$;

- the share of direct investment in transport and logistics in the total direct investment in all types of economic activity in the region (\%) by $2 \%$;

- the share of capital investments in the field of transport and warehousing in the total amount of capital investments in all types of economic activity in the region (\%) by $3 \%$;

- the average number of employees in the field of transport and warehousing by $1.5 \%$, including in the field of land and pipeline, water, air transport - by $1 \%$;

The reduction of:

- costs for organization of logistics activities by $12 \%$ due to reducing the transport component in the cost of services by $7 \%$;

- average downtime of cars under one freight operation of the Prydniprovsky Railway (hours) by $25 \%$.

\section{Conclusions}

As a result of the study, it was found that in the Prydniprovsky economic region there is a significant logistical and transit potential for developing the regional transport and logistics system. However, this requires the creation of appropriate institutional conditions, namely:

- to improve the legal regulation of the transport sector development and the logistics activities organization, taking into account the regional component;

- to develop a Strategy for the integrated development of the regional transport and logistics system based on modernizing the transport infrastructure and creating a transport and logistics cluster;

- to increase the efficiency of organizing logistics activities and functioning the port infrastructure in sea trade ports;

- to form optimal multimodal logistics chains and to substantiate the regional cluster pattern of organizing logistics activities in the economic region;

- to develop and implement an organizational and economic mechanism for managing the development of the transport and logistics system in the economic region using the "green" logistics tools and digital technologies; 
- to improve the mechanism of financial support for developing the transport and logistics system by using such financial instruments as venture capital, crowdfunding, factoring, international-private-public partnership based on attracting private investment, credit institutions, foreign investment resources, grants from international financial organizations.

The implementation of the proposed conceptual approach to creating a transport and logistics cluster in the Prydniprovsky economic region will help to obtain a synergistic effect, the components of which are:

- economic effect: increasing the level of the territories' investment attractiveness; magnifying budgets revenues (regional, local) due to forming a qualitatively new pattern of regional economy, strengthening the area's competitive advantages and increasing the economic capacity of territorial communities under conditions of decentralization; the growing level of transit potential; increasing the freight traffic and cargo turnover of various means of transport; decreasing the costs of organizing logistics activities by reducing the transport component in the cost of services, the time to perform customs procedures for goods' clearance; ensuring favorable institutional conditions for functioning the logistics services market; improving transportation technology by using modern information and communication technologies and digital logistics;

- social: job creation and employment growth; improving the working conditions of workers employed in the field of transport and warehousing;

- environmental: reduction of greenhouse gas emissions from transport by optimizing traffic flows; increasing the level of environmental safety.

Prospects for further research are to summarize the international experience of creating transport and logistics clusters and justify and develop a cluster pattern of logistics activities in the economic regions of Ukraine, taking into account their regional specificity.

\section{Conflicts of Interest}

The authors declare no conflict of interest.

\section{References}

Abazov, R. (2021). Education for sustainable development and ICT: The case of MDP program at alFarabi KazNU. Herald of Journalism, 58(4), 34-43. https://doi.org/10.26577/HJ.2020.v58.i4.04

Arefieva, O., Polous, O., Arefiev, S., Tytykalo, V., \& Kwilinski, A. (2021). Managing Sustainable Development by Human Capital Reproduction in the System of Company's Organizational Behaviour. IOP Conference Series: Earth and Environmental Science, 628, 012039.

Beresford, A.K.C., Pettit, S.J., \& Whittaker, W. (2005). Improving Supply Chain Performance through Quality Management in a Global Distribution Environment. International Journal of Services and Operations Management, 1(1), 75-89. https://doi.org/ 10.1504/IJSOM.2005.006319 
Blaik, P. (2010). Logistyka. Koncepcja zintegrowanego zarzadzania. Warszawa: Polskie Wydawnictwo Ekonomiczne.

Boiko, V., Kwilinski, A., Misiuk, M., \& Boiko, L. (2019). Competitive Advantages of Wholesale Markets of Agricultural Products as a Type of Entrepreneurial Activity: The Experience of Ukraine and Poland. Economic Annals-XXI, 175(1-2), 68-72. https://doi.org/10.21003/ea.V175-12

Bogachov, S., Kwilinski, A., Miethlich, B., Bartosova, V., \& Gurnak, A. (2020). Artificial Intelligence Components and Fuzzy Regulators in Entrepreneurship Development. Entrepreneurship and Sustainability Issues, 8(2), 487-499. http://doi.org/10.9770/jesi.2020.8.2(29)

Borychowski, M., Stępień, S., Polcyn, J., Tošović-Stevanović, A., Ćalović, D., Lalić, G., \& Žuža, M. (2020). Socio-Economic Determinants of Small Family Farms' Resilience in Selected Central and Eastern European Countries. Sustainability, 12(24), 10362. doi:10.3390/su122410362

Bowersox, D. J., \& Closs, D. J. (2017). Logistika: integrirovannaja tsep postavok. 2-e izd. [Logistic: Integrated Supply Chain. 2nd ed.]. Moscow: Olymp-Business. [in Russian].

Box, J., \& Jenkins, G. (1974). Analiz vremennykh ryadov: prognoz i upravlenie [Time Series Analysis: Forecast and Management]. Moscow: MIR. [in Russian].

Burlaka, O., Kuzior, A., Hanych, O., Kravchenko, S., \& Melnychenko, O. (2019). Implementation and legal regulation of e lectronic insurance in Ukraine. Journal of Legal, Ethical and Regulatory Issues, 22(Special Issue 2), 1-5. Retrieved from https://www.abacademies.org/articles/Implementationand-legal-regulation-of-electronic-insurance-in-Ukraine-1544-0044-22-SI-2-356.pdf

Chygryn, O., Bilan, Y., \& Kwilinski, A. (2020). Stakeholders of Green Competitiveness: Innovative Approaches for Creating Communicative System. Marketing and Management of Innovations, 3, 356-368. https://doi.org/10.21272/mmi.2020.3-26

Center for Transport Strategies. (2018). Gosudarstvenno-chastnoe partnerstvo $v$ infrastrukture. Otraslevoy kontrol [Public-Private Partnership in Infrastructure. Industry Control]. Kyiv, Ukraine: Center for Transport Strategies.

Czyżewski, B., Matuszczak, A., \& Miskiewicz, R. (2019). Public Goods Versus The Farm Price-Cost Squeeze: Shaping the Sustainability of the EU's Common Agricultural Policy. Technological and Economic Development of Economy, 25(1), 82-102. https://doi.org/10.3846/tede.2019.7449

Czyżewski, B., Matuszczak, A., Polcyn, J., Smędzik-Ambroży, K., \& Staniszewski, J. (2020). Deadweight Loss in Environmental Policy: The Case of the European Union Member States. Journal of Cleaner Production, 260, 121064. https://doi.org/10.1016/j.jclepro.2020.121064

Dalevska, N. (2013). Methodological issues of social order relationships analysis in categorial structures of international political economy. Economic Annals-XXI, 11-12(1), 12-15.

Dalevska, N., Khobta, V., Kwilinski, A., \& Kravchenko, S. (2019). A Model for Estimating Social and Economic Indicators of Sustainable Development. Entrepreneurship and Sustainability Issues, 6(4), 1839-1860. https://doi.org/10.9770/jesi.2019.6.4(21)

Dementyev, V. V. (2013). On Some Peculiarities of the Subject of Institutional Theory. Journal of Institutional Studies, 5(3), 5-13.

Dementyev, V. V. (2015). Institutional Political Economy: Where to Start? Journal of Institutional Studies, 7(1),25-44. https://doi.org/10.17835/2076-6297.2015.7.1.025-044

Dementyev, V. V. (2019). Innovation: Between the Coase Theorem and the Hobbes Theorem. Journal of Institutional Studies, 11(1), 95-114. https://doi.org/10.17835/2076-6297.2019.11.1.095-114

Dementyev, V.V., \& Scherbakov, A. P. (2017). Profit And Economic Growth. Terra Economicus, 15(3), 75-91. https://doi.org/10.23683/2073-6606-2017-15-3-75-91 
Dementyev, V.V., \& Kwilinski, A. (2020). Institutsionalnaya sostavlyayuschaya izderzhek proizvodstva [Institutional Component of Production Costs]. Journal of Institutional Studies, 12(1), 100-116. https://doi.org/10.17835/2076-6297.2020.12.1.100-116 [in Russian].

Dmukhovski, R. (2019). Poniattia lohistychnykh klasteriv ta efektyvnosti ekonomichnykh pidpryiemstv [The Concept of Logistics Clusters and Efficiency of Economic Enterprises]. Journal of the European Economy, 18(3), 296-306. https://doi.org/10.35774/jec2019.03.351 [in Ukrainian].

Drozdz, W., Miskiewicz, R., Pokrzywniak, J., \& Elzanowski, F. (2019). Urban Electromobility in the Context of Industry 4.0. Torun: Wydawnictwo Adam Marszalek.

Drozdz, W., Marszalek-Kawa, J., Miskiewicz, R., \& Szczepanska-Waszczyna, K. (2020). Digital Economy in the Comporary World. Torun: Wydawnictwo Adam Marszalek.

Dzwigol, H. (2019a). The Concept of the System Approach of the Enterprise Restructuring Process. Virtual Economics, 2(4), 46-70. https://doi.org/10.34021/ve.2019.02.04(3)

Dzwigol, H. (2019b). Research Methods and Techniques in New Management Trends: Research Results. Virtual Economics, 2(1), 31-48. https://doi.org/10.34021/ve.2019.02.01(2)

Dzwigol, H. (2020a). Innovation in Marketing Research: Quantitative and Qualitative Analysis. Marketing and Management of Innovations, 1, 128-135. http://doi.org/10.21272/mmi.2020.1-10

Dzwigol, H. (2020b). Methodological and Empirical Platform of Triangulation in Strategic Management. Academy of Strategic Management Journal, 19(4), 1-8.

Dzwigol, H. (2020c). Tools for Adjusting Research Methods and Techniques to Research Processes. Economic Herald of the Donbas, 4(62), 110-118.

Dzwigol, H. (2020d). Interim Management as a New Approach to the Company Management. Review of Business and Economics Studies, 8(1), 20-26. https://doi.org/10.26794/2308-944X-2020-8-1-2026.

Dzwigol, H. (2021). Meta-Analysis in Management and Quality Sciences. Marketing and Management of Innovation, 1, 324-335. https://doi.org/10.21272/mmi.2021.1-25

Dźwigoł, H., \& Dźwigoł-Barosz, M. (2018). Scientific Research Methodology in Management Sciences. Financial and Credit Activity: Problems of Theory and Practice, 2(25), 424-437.

Dzwigol, H., \& Dzwigol-Barosz, M. (2020a). Sustainable Development of the Company on the Basis of Expert Assessment of the Investment Strategy. Academy of Strategic Management Journal, 19(5), 1-7.

Dzwigol, H., \& Dzwigol-Barosz, M. (2020b). Determinants of the World Investment Market Development in the Context of Global Transformations. In Khalid S. Soliman (Ed.), Proceedings of the 36th International Business Information Management Association (IBIMA) 4-5 November 2020 (pp. 9109-9116). Granada, Spain: IBIMA Publishing.

Dzwigol, H., Shcherbak, S., Semikina, M., Vinichenko, O., \& Vasiuta, V. (2019a). Formation of Strategic Change Management System at an Enterprise. Academy of Strategic Management Journal, 18(SI1), 1-8.

Dzwigol, H., Aleinikova, O., Umanska, Y., Shmygol, N., \& Pushak, Y. (2019b). An Entrepreneurship Model for Assessing the Investment Attractiveness of Regions. Journal of Entrepreneurship Education, 22(1S), 1-7.

Dzwigoł, H., Dzwigoł-Barosz, M., Zhyvko, Z., Miskiewicz, R., \& Pushak, H. (2019c). Evaluation of the Energy Security as a Component of National Security of the Country. Journal of Security and Sustainability Issues, 8(3), 307-317. http://doi.org/10.9770/jssi.2019.8.3(2) 
Dzwigol, H., Dźwigoł-Barosz, M., Kwilinski, A. (2020a). Formation of Global Competitive Enterprise Environment Based on Industry 4.0 Concept. International Journal of Entrepreneurship, 24(1), 1-5.

Dzwigol, H., Dzwigol-Barosz, M., Miskiewicz, R., \& Kwilinski, A. (2020b). Manager Competency Assessment Model in the Conditions of Industry 4.0. Entrepreneurship and Sustainability Issues, 7(4), 2630-2644. https://doi.org/10.9770/jesi.2020.7.4(5)

European Cluster Collaboration Platform. (2016). Smart Guide to Cluster Policy. Guidebook Series How to support SME Policy from Structural Funds. Belgium: European Commission. https://doi.org/10.2873/48105

Frankowska, M. (2015). Klastry logistyczne jako ogniwa globalnych lancuchow dostaw. Logistyka, 3, 5633-5637.

Gorynia, M. (2019). Competition and Globalisation in Economic Sciences. Selected Aspects. Economics and Business Review, 5(3), 118-133. https://doi.org/10.18559/ebr.2019.3.7

Gorynia, M., Trąpczyński, P., \& Bytniewski, S. (2019). The Concepts of Strategy and Business Models in Firm Internationalization Research: Towards a Research Agenda. International Entrepreneurship Review, 5(2), 7-21. https://doi.org/10.15678/ier.2019.0502.01

Gunasekaran, A. (2005). Editorial: New Service and Manufacturing Environments: Challenges for Operations Management Researchers and Practitioners. International Journal of Services and Operations Management, 1(1), 1-6. https://doi.org/ 10.1504/IJSOM.2005.006313

Hryhorak, M.Yu. (2017). Intelektualizatsiia rynku lohistychnykh posluh: kontseptsii, metodolohiia, kompetentnist [Intellectualization of the Logistics Services Market: Concepts, Methodology, Competence]. Kyiv: Juice Groups Ukraine. [in Ukrainian].

Hrytsenko, S.I. (2019). Modeliuvannia systemy tsinnostei ekolantsiuha postachan yak dominanta transportno-lohistychnykh klasteriv [Modeling the System of Values of the Ecological Supply Chain as the Dominant Transport and Logistics Clusters]. Bulletin of Economic Science of Ukraine, 1(36), 31-34. [in Ukrainian].

Huemer, L. (2006). Supply Management: Value Creation, Coordination and Positioning in Supply Relationships. Long Range Planning, 39(2), 133-153. https://doi.org/ 10.1016/j.Irp.2006.04.005

Ilchenko, S.V., \& Karpenko, H.Yu. (2017). Assessment of the Transport Infrastructure Impact on the Regional Development. In Economic Innovations, 65. Odessa: IPMEER NAS of Ukraine (pp. 67-72). https://doi.org/10.31520/ei.2017.19.3(65).67-72

Ivanov, S. V., \& Kharazishvili, Yu. M. (2017). Innovacijni faktory rozvytku transportnoji systemy Ukrajiny [Innovative Factors of Development of the Transport System of Ukraine]. Bulletin of Economic Science of Ukraine, 2, 47-55. [in Ukrainian].

Ivanov, S. V., Liashenko, V. I., \& Trushkina, N. V. (2019a). Innovatsiinyi rozvytok transportnolohistychnoi systemy v Ukraini: problemy ta shliakhy yikh vyrishennia [Innovative Development of the Transport and Logistics System in Ukraine: Problems and Solutions]. In V.I. Liashenko, O.V. Prokopenko, and V.A. Omelyanenko (Eds.), Instytutsionalna model innovatsiinoi ekonomiky [Institutional Model of Innovative Economy] (pp. 114-130). Kyiv: Institute of Industrial Economics of the NAS of Ukraine. [in Ukrainian].

Ivanov, S. V., Liashenko, V. I., \& Trushkina, N. V. (2019b). Peredumovy formuvannia ta perspektyvy rozvytku transportno-lohistychnoho klastera $\mathrm{v}$ Prychornomorskomu ekonomichnomu raioni [Prerequisites for Formation and Development Prospects of the Transport and Logistics Cluster in the Black Sea Economic Region]. Black Sea Economic Studies, 46(2), 16-24. https://doi.org/10.32843/bses.46-25. [in Ukrainian]. 
Ivanov, S., Dzwigol, H., \& Trushkina, N. (2019c). Proposals for the Formation of a Transport and Logistics Cluster as an Institution of Regional Development (on the Example of Donetsk Economic Region). Economic Herald of the Donbas, 4(58), 51-60. https://doi.org/10.12958/1817-3772-2019-4(58)-5160

Ivanov, S.V., Liashenko, V.I., \& Trushkina, N.V. (2020). Pravovi aspekty stvorennia transportnolohistychnykh klasteriv v rehionakh Ukrainy [Legal Aspects of Creating Transport and Logistics Clusters in the Regions of Ukraine]. In Gesellschaftsrechtliche Transformationen von wirtschaftlichen Systemen in den Zeiten der Neo-Industrialisierung (pp. 661-668). Nüremberg: Verlag SWG imex GmbH [in Ukrainian].

Kaźmierczyk, J., \& Chinalska, A. (2018). Flexible forms of employment, an opportunity or a curse for the modern economy? Case study: banks in Poland. Entrepreneurship and Sustainability Issues, 6(2), 782-798. https://doi.org/10.9770/jesi.2018.6.2(21)

Kharazishvili, Y., Kwilinski, A., Grishnova, O., Dzwigol, H. (2020). Social Safety of Society for Developing Countries to Meet Sustainable Development Standards: Indicators, Level, Strategic Benchmarks (with Calculations Based on the Case Study of Ukraine). Sustainability, 12(21), 89-53. https://doi.org/10.3390/su12218953

Kharazishvili, Y., Kwilinski, A., Sukhodolia, O., Dzwigol, H., Bobro, D., \& Kotowicz, J. (2021). The Systemic Approach for Estimating and Strategizing Energy Security: The Case of Ukraine. Energies, 14(8), 2126. https://doi.org/10.3390/en14082126

Koibichuk, V., Ostrovska, N., Kashiyeva, F., \& Kwilinski, A. (2021). Innovation Technology and Cyber Frauds Risks of Neobanks: Gravity Model Analysis. Marketing and Management of Innovations, 1, 253-265. http://doi.org/10.21272/mmi.2021.1-19

Kondratenko, V., Okopnyk, O., Ziganto, L., \& Kwilinski, A. (2020). Innovation Development of Public Administration: Management and Legislation Features. Marketing and Management of Innovations, 1, 87-94. https://doi.org/10.21272/mmi.2020.1-06

Kotler, P., \& Keller, K. L. (2014). Marketing Management. 14th ed. Upper Saddle River, New Jersey: Prentice Hall.

Kruczek, M., \& Zebrucki, Z. (2014). Koncepcja klastrow logistycznych. Zeszyty naukowe Politechniki Slaskiej. Seria: Organizacja i zarzadzanie, 70, 229-241.

Kuzior, A., Kwilinski, A., \& Tkachenko, V. (2019). Sustainable Development of Organizations Based on the Combinatorial Model of Artificial Intelligence. Entrepreneurship and Sustainability, 7(2), 13531376. http://doi.org/10.9770/jesi.2019.7.2(39)

Kvilinskyi, O.S. (2012). Formirovanie dopolnitel'nyh preimushchestv funkcionirovaniya i razvitiya malyh predpriyatij [Formation of Additional Benefits of Operation and Development of Small Enterprises]. Economy of Industry, 3-4(59-60), 140-147. [in Russian].

Kvilinskyi, O., \& Kravchenko, S. (2016). Optimization of Innovative Project Realization Conditions. Zeszyty Naukowe Politechniki Poznańskiej. Organizacja i Zarzqqdzanie, 70, 101-111.

Kwilinski, A. (2018a). Mechanism of Modernization of Industrial Sphere of Industrial Enterprise in Accordance with Requirements of the Information Economy. Marketing and Management of Innovations, 4, 116-128. http://doi.org/10.21272/mmi.2018.4-11

Kwilinski, A. (2018b). Mechanism for Assessing the Competitiveness of an Industrial Enterprise in the Information Economy. Research Papers in Economics and Finance, 3(1), 7-16. https://doi.org/10.18559/ref.2018.1.1

Kwilinski, A. (2019). Implementation of Blockchain Technology in Accounting Sphere. Academy of Accounting and Financial Studies Journal, 23(SI2), 1-6. 
Kwilinski, A., \& Trushkina, N. (2019). Logistics Cluster as an Institution of Regional Development in the Context of Economic Modernization. In Science and Practice (pp. 55-59). Thessaloniki, Greece: University of Macedonia, Midas S.A.

Kwilinski, A., Tkachenko, V., \& Kuzior, A. (2019a). Transparent Cognitive Technologies to Ensure Sustainable Society Development. Journal of Security and Sustainability Issues, 9(2), 561-570 http://doi.org/10.9770/jssi.2019.9.2(15)

Kwilinski, A., Drobyazko, S., \& Derevyanko, B. (2019b). Synergetic and Value Effects in Corporate Mergers and Acquisitions of International Companies. In Khalid S. Soliman (Ed.), Proceedings of the 34th International Business Information Management Association Conference (IBIMA) 13-14 November 2019. Vision 2025: Education Excellence and Management of Innovations through Sustainable Economic Competitive Advantage in 2019 (pp. 9467-9471). Madrid, Spain: IBIMA Publishing.

Kwilinski, A., Dalevska, N., Kravchenko, S., Hroznyi, I., Kovalenko, I. (2019c). Formation of the Entrepreneurship Model of E-Business in the Context of the Introduction of Information and Communication Technologies. Journal of Entrepreneurship Education, 22(SI1), 1528-2651-22-S1337: 1-7.

Kwilinski, A., Ruzhytskyi, I., Patlachuk, V., Patlachuk, O., \& Kaminska, B. (2019d). Environmental Taxes as a Condition of Business Responsibility in the Conditions of Sustainable Development. Journal of Legal, Ethical and Regulatory Issues, 22(SI2) 1544-0044-22-SI-2-354: 1-6.

Kwilinski, A., Volynets, R., Berdnik, I., Holovko, M., \& Berzin, P. (2019e). E-Commerce: Concept and Legal Regulation in Modern Economic Conditions. Journal of Legal, Ethical and Regulatory Issues, 22(SI2), 1544-0044-22-SI-2-357: 1-6.

Kwilinski, A., Pajak, K., Halachenko, O., Vasylchak, S., Pushak, Ya., \& Kuzior, P. (2019f). Marketing Tools for Improving Enterprise Performance in the Context of Social and Economic Security of the State: Innovative Approaches to Assessment. Marketing and Management of Innovations, 4, 172-181. http://doi.org/10.21272/mmi.2019.4-14

Kwilinski, A., Dzwigol, H., \& Dementyev, V. (2019f). Transnational Corporations as Entities of International Entrepreneurship. International Journal of Entrepreneurship, 23(SI4), 1-6.

Kwilinski, A., \& Kuzior, A. (2020). Cognitive Technologies in the Management and Formation of Directions of the Priority Development of Industrial Enterprises. Management Systems in Production Engineering, 28(2), 119-123. http://doi.org/10.1515/mspe-2019-0020

Kwilinski, A., Vyshnevskyi, O., \& Dzwigol, H. (2020a). Digitalization of the EU Economies and People at Risk of Poverty or Social Exclusion. Journal of Risk and Financial Management, 13(7), 142. https://doi.org/10.3390/jrfm13070142

Kwilinski, A., Zaloznova, Y., Trushkina, N., \& Rynkevych, N. (2020b). Organizational and Methodological Support for Ukrainian Coal Enterprises Marketing Activity Improvement. E3S Web of Conferences, 168, 00031. https://doi.org/10.1051/e3sconf/202016800031

Kwilinski, A., Dielini, M., Mazuryk, O., Filippov, V., \& Kitseliuk, V. (2020c). System Constructs for the Investment Security of a Country. Journal of Security and Sustainability Issues, 10(1), 345-358. https://doi.org/10.9770/jssi.2020.10.1(25)

Kwilinski, A., Shteingauz, D., \& Maslov, V. (2020d). Financial and Credit Instruments for Ensuring Effective Functioning of the Residential Real Estate Market. Financial and Credit Activities: Problems of Theory and Practice. 3(34), 133-140. https://doi.org/10.18371/fcaptp.v3i34.215448 
Kwilinski, A., Slatvitskaya, I., Dugar, T., Khodakivska, L., \& Derevyanko, B. (2020e). Main Effects of Mergers and Acquisitions in International Enterprise Activities. International Journal of Entrepreneurship, 24(Special Issue), 1-8.

Kwilinski, A., Litvin, V., Kamchatova, E., Polusmiak, J., \& Mironova, D. (2021). Information Support of the Entrepreneurship Model Complex with the Application of Cloud Technologies. International Journal of Entrepreneurship, 25(1), 1-8.

Kyrylov Y, Hranovska V, Boiko V, Kwilinski A, \& Boiko L. (2020). International Tourism Development in the Context of Increasing Globalization Risks: On the Example of Ukraine's Integration into the Global Tourism Industry. Journal of Risk and Financial Management, 13(12), 303. https://doi.org/10.3390/jrfm13120303

Lakhno, V., Malyukov, V., Bochulia, T., Hipters, Z., Kwilinski, A., \& Tomashevska, O. (2018). Model of Managing of the Procedure of Mutual Financial Investing in Information Technologies and Smart City Systems. International Journal of Civil Engineering and Technology, 9(8), 1802-1812.

Liashenko, V.I., Ivanov, S.V., \& Trushkina, N.V. (2020). Transportno-lohistychnyi klaster yak element rehionalnoi innovatsiinoi infrastruktury Prydniprovskoho ekonomichnoho raionu [Transport and Logistics Cluster as an Element of the Regional Innovation Infrastructure of the Prydniprovskyi Economic Region]. In Latest Technologies of Neo-industrial Transformations: Financial, Legal and Sociological Aspects (pp. 220-231). Austria, Steyr: Shioda GmbH. [in Ukrainian].

Lyulyov, O., \& Pimonenko, T. (2017). Lotka-Volterra Model as an Instrument of the Investment and Innovative Processes Stability Analysis. Marketing and Management of Innovations, 1, 159-169. https://doi.org/10.21272/mmi.2017.1-14

Lyulyov, O., \& Shvindina, H. (2017). Stabilisation Pentagon Model: Application in the Management at Macro- and Micro-Levels. Problems and Perspectives in Management, 15(3), 42-52. https://doi.org/10.21511/ppm.15(3).2017.04

Lyulyov, O., Chygryn, O., \& Pimonenko, T. (2018). National Brand as a Marketing Determinant of Macroeconomic Stability. Marketing and Management of Innovations, 3, 142-152, https://doi.org/10.21272/mmi.2018.3-12

Lyulyov, O., Us, Y., Pimonenko, T., Kwilinski, A., Vasylieva, T., Dalevska, N., Polcyn, J., \& Boiko, V. (2020a). The Link Between Economic Growth and Tourism: Covid-19 Impact. In Khalid S. Soliman (Ed.), Proceedings of the 36th International Business Information Management Association (IBIMA) 4-5 November 2020. (pp. 8070-8086). Granada, Spain: IBIMA Publishing.

Lyulyov, O., Pimonenko, T., Kwilinski, A., Us, Y., Arefieva, O., Akimov, O., \& Pudryk, D. (2020b). Government Policy on Macroeconomic Stability: Case for Low- and Middle- Income Economies. In Khalid S. Soliman (Ed.), Proceedings of the 36th International Business Information Management Association (IBIMA) 4-5 November 2020 (pp. 8087-8101). Granada, Spain: IBIMA Publishing.

Lyulyov, O., Pimonenko, T., Kwilinski, A., Dzwigol, H., Dzwigol-Barosz, M., Pavlyk, V., \& Barosz, P. (2021a). The Impact of the Government Policy on the Energy Efficient Gap: The Evidence from Ukraine. Energies, 14(2), 373. https://doi.org/10.3390/en14020373

Lyulyov, O., Pimonenko, T., Kwilinski, A., \& Us, Y. (2021b). The Heterogeneous Effect of Democracy, Economic and Political Globalisation on Renewable Energy. E3S Web of Conferences, 250, 03006. https://doi.org/10.1051/e3sconf/202125003006

Melnychenko, O. (2019). Application of artificial intelligence in control systems of economic activity. Virtual Economics, 2(3), 30-40. https://doi.org/10.34021/ve.2019.02.03(3)

Melnychenko, O. (2020). Is Artificial Intelligence Ready to Assess an Enterprise's Financial Security? Journal of Risk and Financial Management, 13(9), 191. https://doi.org/10.3390/jrfm13090191 
Melnychenko, O. (2021). The Energy of Finance in Refining of Medical Surge Capacity. Energies, 14, 210. https://doi.org/10.3390/en14010210

Mlaabdal, S., Chygryn, O., Kwilinski, A., Muzychuk, O., \& Akimov, O. (2020). Economic Growth and Oil Industry Development: Assessment of the Interaction of National Economy Indicators. In Khalid S. Soliman (Ed.), Proceedings of the 36th International Business Information Management Association (IBIMA) 4-5 November 2020 (pp. 8102-8114). Granada, Spain: IBIMA Publishing.

Miskiewicz, R. (2017a). Knowledge in the Process of Enterprise Acquisition. Progress in Economic Sciences, 4, 415-432. https://doi.org/10.14595/PES/04/029

Miskiewicz, R. (2017b). Knowledge Transfer in Merger and Acquisition Processes in the Metallurgical Industry. Warsaw: PWN.

Miskiewicz, R. (2018). The Importance of Knowledge Transfer on the Energy Market. Polityka Energetyczna, 21(2), 49-62. http://dx.doi.org/10.24425\%2F122774

Miskiewicz, R. (2019). Challenges Facing Management Practice in the Light of Industry 4.0: The Example of Poland. Virtual Economics, 2(2), 37-47. https://doi.org/10.34021/ve.2019.02.02(2)

Miskiewicz, R. (2020a). Internet of Things in Marketing: Bibliometric Analysis. Marketing and Management of Innovations, 3, 371-381. http://doi.org/10.21272/mmi.2020.3-27

Miskiewicz, R. (2020b). Efficiency of Electricity Production Technology from Post-Process Gas Heat: Ecological, Economic and Social Benefits. Energies, 13(22), 6106. https://doi.org/10.3390/en13226106

Miśkiewicz, R. (2021). The Impact of Innovation and Information Technology on Greenhouse Gas Emissions: A Case of the Visegrád Countries. Journal of Risk and Financial Management, 14(2), 59. https://doi.org/10.3390/jrfm14020059

Miśkiewicz, R, \& Wolniak, R. (2020). Practical Application of the Industry 4.0 Concept in a Steel Company. Sustainability, 12(14), 5776. https://doi.org/10.3390/su12145776

Murphy, P. R., \& Wood, D. F. (2017). Sovremennaja logistika. 8-e izd. [Modern Logistic. 8th ed.] Moscow: I. D. Williams LLC. [in Russian].

Nykyforuk, O. I. (2014). Modernizatsiia nazemnykh transportnykh system Ukrainy [Modernization of the Land Transport Systems of Ukraine]. Kyiv: Institute of Economics and Forecasting of NAS of Ukraine. [in Ukrainian].

Nykyforuk, O. I. (Ed.). (2017). Rozvytok infrastrukturnykh sektoriv yak chynnyk realizatsii priorytetnykh napriamiv ekonomichnoi polityky Ukrainy [Development of Infrastructure Sectors as a Factor of Realizing Priority Directions of the Economic Policy of Ukraine]. Kyiv: Institute of Economics and Forecasting of NAS of Ukraine. [in Ukrainian].

Nykyforuk, O. I., Stasiuk, O. M., Chmyrova, L. Yu., \& Fediai, N. O. (2019). Tsyfrovizatsiia v transportnomu sektori: tendentsii ta indykatory rozvytku. Chastyna 1 [Digitization in the Transport Sector: Trends and Indicators of Development. Part 1]. Statistics of Ukraine, 3, 70-81. https://doi.org/ 10.31767/su.3(86)2019.03.08 [in Ukrainian].

Pająk, K., Kamińska, B., \& Kvilinskyi, O. (2016). Modern Trends of Financial Sector Development under the Virtual Regionalization Conditions. Financial and Credit Activity: Problems of Theory and Practice, 2(21), 204-217. https://doi.org/10.18371/fcaptp.v2i21.91052

Pająk, K., Kvilinskyi, O., Fasiecka, O., \& Miskiewicz, R. (2017). Energy security in regional policy in Wielkopolska region of Poland. Economics and Environment, 2(61), 122-138. 
Pimonenko, T., \& Lyulyov, O. (2019). Marketing strategies of green investments: main provisions and basic features. Herald of Ternopil National Economic University, (1), 177-185. doi:https://doi.org/10.35774/visnyk2019.01.177

Porter, M. E. (1998). Clusters and the New Economics of Competition. Harvard Business Review, 76(6), 77-90.

Prokopenko, O., \& Miskiewicz, R. (2020). Perception of "Green Shipping" in the Contemporary Conditions. Entrepreneurship and Sustainability Issues, 8(2), 269-284. https://doi.org/10.9770/jesi.2020.8.2(16)

Saługa, P.W., Szczepańska-Woszczyna, K., Miśkiewicz, R., \& Chłąd, M. (2020). Cost of Equity of CoalFired Power Generation Projects in Poland: Its Importance for the Management of DecisionMaking Process. Energies, 13(18), 4833. https://doi.org/10.3390/en13184833

Savchenko, T., Basiurkina, N., Rodina, O., \& Kwilinski, A. (2019). Improvement of the Assessment Methods of Product Competitiveness of the Specialized Poultry Enterprises. Management Theory and Studies for Rural Business and Infrastructure Development, 41(1), 43-61. https://doi.org/10.15544/mts.2019.05

Shamileva, L.L. (2008). Statisticheskoe modelirovanie i prognozirovanie [Statistical Modeling and Forecasting]. Donetsk: DonNU. [in Russian].

Shelobaev, S.I. (2000). Matematicheskie metody i modeli $v$ ekonomike, finansakh, biznese [Mathematical Methods and Models in Economics, Finance, Business]. Moscow: UNITY-DANA. [in Russian].

Sokolenko, S. I. (2004). Klastery v hlobalnii ekonomitsi [Clusters in the Global Economy]. Kyiv: Lohos.

State Statistics Service of Ukraine. (2015a). Export, Import and Transit of Goods in Ukraine for 20102014. Retrieved from http://www.ukrstat.gov.ua/ [in Ukrainian].

State Statistics Service of Ukraine. (2015b). Cargo Processing in Sea (River) Ports (Berths) of Ukraine for 2010-2014. Retrieved from http://www.ukrstat.gov.ua/ [in Ukrainian].

State Statistics Service of Ukraine. (2019). Transport and Communications of Ukraine - 2018. Kyiv, (pp. 46, 50). Retrieved from http://www.ukrstat.gov.ua/ [in Ukrainian].

State Statistics Service of Ukraine. (2020a). Capital Investments by Types of Economic Activity for 20102019. Retrieved from http://www.ukrstat.gov.ua/ [in Ukrainian].

State Statistics Service of Ukraine. (2020b). Direct Investment by Type of Economic Activity for 20102019. Retrieved from http://www.ukrstat.gov.ua/ [in Ukrainian].

State Statistics Service of Ukraine. (2020c). Transport of Ukraine 2019. Kyiv, (pp. 42). Retrieved from http://www.ukrstat.gov.ua/ [in Ukrainian].

State Statistics Service of Ukraine. (2020d). Volumes of Export-Import of Goods for 2010-2019. Retrieved from http://www.ukrstat.gov.ua/ [in Ukrainian].

Szuster, M. (2012). Rola klastrow we wspieraniu innowacyjnosci [The Role of Clusters in Supporting Innovation]. Ekonomiczne Problemy Uslug, 94, 311-325.

The Ukrainian Sea Ports Authority. (2020). Total Cargo Processing by Stevedoring Companies in Seaports for 2012-2019. Retrieved from http://www.uspa.gov.ua/pokazniki-roboti [in Ukrainian].

Tkachenko, V., Kwilinski, A., Korystin, O., Svyrydiuk, N., \& Tkachenko, I. (2019a). Assessment of Information Technologies Influence on Financial Security of Economy. Journal of Security and Sustainability, 8(3), 375-385. http://doi.org/10.9770/jssi.2019.8.3(7)

Tkachenko, V., Kwilinski, A., Klymchuk, M., \& Tkachenko, I. (2019b). The Economic-Mathematical Development of Buildings Construction Model Optimization on the Basis of Digital Economy. 
Management Systems in Production Engineering, 27(2), 119-123. http://doi.org/10.1515/mspe2019-0020

Tkachenko, V., Kwilinski, A., Tkachenko, I., \& Puzyrova, P. (2019c). Theoretical and Methodical Approaches to the Definition of Marketing Risks Management Concept at Industrial Enterprises. Marketing and Management of Innovations, 2, 228-238. http://doi.org/10.21272/mmi.2019.2-20

Tkachenko, V., Kwilinski, A., Kaminska, B., Tkachenko, I., \& Puzyrova, P. (2019d). Development and Effectiveness of Financial Potential Management of Enterprises in Modern Conditions. Financial and Credit Activity: Problems of Theory and Practice, 3(30), 85-94. https://doi.org/10.18371/fcaptp.v3i30.179513

Tkachenko, V., Kuzior, A., \& Kwilinski, A. (2019e). Introduction of Artificial Intelligence Tools into the Training Methods of Entrepreneurship Activities. Journal of Entrepreneurship Education, 22(6), 110.

Trushkina, N.V. (2019a). Formuvannja integhrovanoji transportno-loghistychnoji systemy v Ukrajini: finansovo-pravovyj aspekt [Formation of Integrated Transport and Logistics System in Ukraine: Financial and Legal Aspect]. In Emergence of Public Development: Financial and Legal Aspects (pp. 619-629). Coventry, United Kingdom: Agenda Publishing House. [in Ukrainian].

Trushkina, N. (2019b). Financial Ensuring Mechanism of Management Innovative Development of the Transport-Logistics System. In Organizational-Economic Mechanism of Management Innovative Development of Economic Entities. Vol.3. (pp. 227-236). Przeworsk: WSSG.

Voinarenko, M. P. (2011) Klastery $v$ instytutsiinii ekonomitsi [Clusters in the Institutional Economy]. Khmelnytskyi, Ukraine: KhNU, Triada-M. [in Ukrainian].

World Bank. (2020). Vdoskonalennia upravlinnia portovoiu haluzziu Ukrainy. Konsolidatsiia kontroliu za korystuvanniam portovymy terytoriiamy ta nablyzhennia do modeli upravlinnia "port-lendlord»: svitovyi dosvid i perspektyvy reformuvannia v ukrainskomu konteksti [The World Bank. Improving the Management of the Ukrainian Port Industry. Consolidation of the Port Area Management Control and Approximation to the Port-Landlord Management Model: World Experience and Reform Perspectives in the Ukrainian Context]. Kyiv, Ukraine: World Bank. [in Ukrainian].

Wyrwa, J., \& Kaźmierczyk, J. (2020). Conceptualizing job satisfaction and its determinants: A systematic literature review. Ekonomicheskaya Sotsiologiya, 21(5), 138-168.

Yerina, A.M. (2001). Statystychne modeliuvannia ta prohnozuvannia [Statistical Modeling and Forecasting]. Kyiv: KNEU. [in Ukrainian].

Zrobek, J. (2011). Marketing w klastrach logistycznych. Acta Universitatis Lodziennsis. Folia Oeconomica, 251, 5-16. 